\title{
CHARACTERIZATION OF BOTRYTIS CINEREA RESISTANCE TO FUNGICIDES IN CALIFORNIA STRAWBERRY PRODUCTION
}

\author{
A Thesis \\ presented to \\ the Faculty of California Polytechnic State University, \\ San Luis Obispo
}

\begin{abstract}
In Partial Fulfillment
of the Requirements for the Degree
\end{abstract}

Master of Science in Agriculture with a Specialization in Plant Protection Science

by

Scott D. Cosseboom

March 2018 
(C) 2018

Scott Cosseboom

ALL RIGHTS RESERVED 


\section{COMMITTEE MEMBERSHIP}

TITLE: $\quad$ Characterization of Botrytis cinerea

Resistance to Fungicides in

California Strawberry Production

AUTHOR: $\quad$ Scott D. Cosseboom

DATE SUBMITTED:

March 2018

COMMITTEE CHAIR:

Kelly L. Ivors, Ph.D.

Associate Professor of Horticulture and Crop Science

Cal Poly San Luis Obispo

COMMITTEE MEMBER:

Guido Schnabel, Ph.D.

Professor of Plant Pathology,

Department of Plant and

Environmental Science

Clemson University

COMMITTEE MEMBER:

Gerald J. Holmes, Ph.D.

Director, Strawberry Center

Cal Poly San Luis Obispo 


\section{ABSTRACT \\ CHARACTERIZATION OF BOTRYTIS CINEREA RESISTANCE TO \\ FUNGICIDES IN CALIFORNIA STRAWBERRY PRODUCTION}

Scott D. Cosseboom

Gray mold of strawberry, caused by Botrytis cinerea, is a very destructive pre- and post-harvest fruit rot. Outside of California, fungicide resistance in $B$. cinerea has been reported to every site-specific chemical class labeled for use against gray mold. One objective of this study was to characterize the resistance of 888 isolates of $B$. cinerea from California strawberry fields to ten active ingredients. Isolates were collected from the same planting block in 47 fields during the early-season (0 to 8 fungicide applications) and late-season (16 to 26 fungicide applications) of 2016. Sensitivity of each isolate was determined using the following active ingredients at a discriminatory dosage $(\mu \mathrm{g} / \mathrm{ml})$ : boscalid (75), cyprodinil (4), fenhexamid (50), fludioxonil (0.5), fluopyram (10), iprodione (10), isofetamid (5), penthiopyrad (5), pyraclostrobin (10), and thiophanate-methyl (100). Resistance to each active ingredient was observed at varied frequencies (early-season \%, late-season \%): boscalid $(12,35)$, cyprodinil $(12,46)$, fenhexamid $(53,91)$, fludioxonil $(1,4)$, fluopyram $(2,7)$, iprodione $(25,8)$, isofetamid $(0,1)$, penthiopyrad $(8,25)$, pyraclostrobin $(77,98)$, and thiophanatemethyl $(81,96)$. Captan, boscalid, cyprodinil, fenhexamid, and fludioxonil were the most commonly used fungicides in surveyed strawberry fields. A selection of 100 isolates was identified to the species level. All isolates were B. cinerea, excluding one isolate of Botrytis mali. A fungicide resistance trial was conducted 
to observe resistance responses in populations of $B$. cinerea. Frequencies of resistance to boscalid and fludioxonil remained unchanged despite consecutive applications of these fungicides. Frequency of resistance to fenhexamid increased when this fungicide was applied and decreased when it was not. This occurred in fungicide treatments including fungicide rotation, tank-mixing with captan, and consecutive applications of fenhexamid. Multi-fungicide resistance was widespread in California strawberries; isolates resistant to fenhexamid, thiophanate-methyl and pyraclostrobin were the most common phenotype. The frequency of resistance increased from the early-season to late-season for multiple active ingredients tested. This within-season change in frequency of resistance was tested and confirmed in a field trial, where common resistance management strategies failed to prevent the buildup of fenhexamid resistance. New and improved methods of resistance management may need to be enacted to ensure the future efficacy of site-specific fungicides. 


\section{ACKNOWLEDGMENTS}

I would like to thank the CDFA Specialty Crop Block Grant Program and the California Strawberry Commission for funding this research project. Also, sincere thanks to Dr. Guido Schnabel and Karen Bryson for their advice and valuable work on this project. I would like to thank Dr. Kelly Ivors for access to your lab, your friendliness and helpfulness, and for giving me the opportunity to start working in your lab as an undergraduate. To my advisor, Dr. Gerald Holmes, thank you for choosing me and taking me on as a student. You have helped me gain invaluable experience and grow in many life skills that are going to serve me well. Thank you to Mark Edsall, Dan Chellemi, Sage Finch, Randy Widerburg, and to over 30 strawberry fruit growers for collaborating with me during my sampling. Thank you to Jason Sharrett and Russel White for helping with GIS and data acquisition. Most of all, I thank God for giving me peace throughout every trial during my graduate experience. 


\section{TABLE OF CONTENTS}

Page

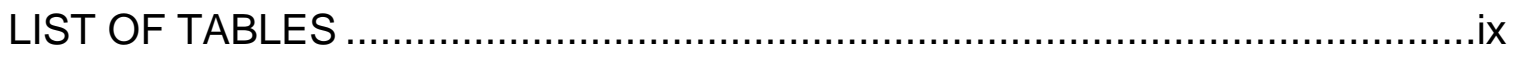

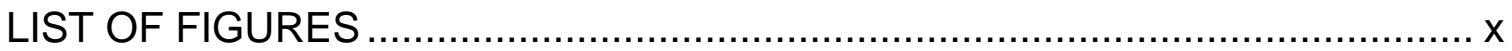

CHAPTER

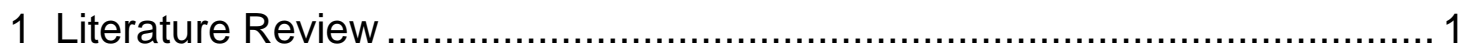

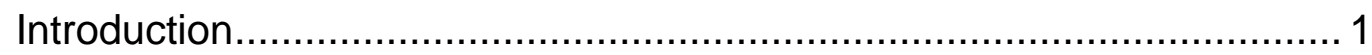

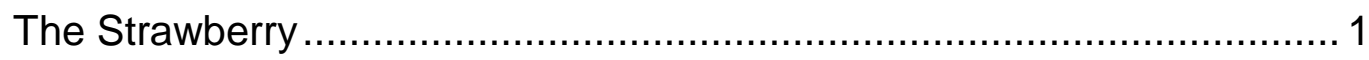

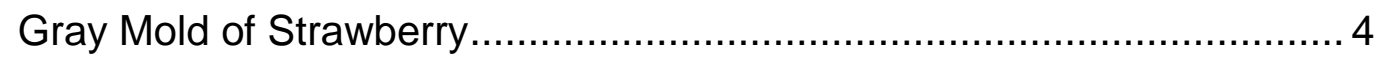

Fungicide Resistance ............................................................... 9

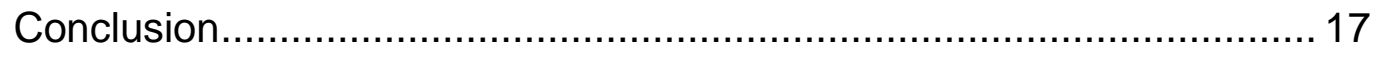

2 Within-season shift in fungicide resistance profiles of Botrytis cinerea in

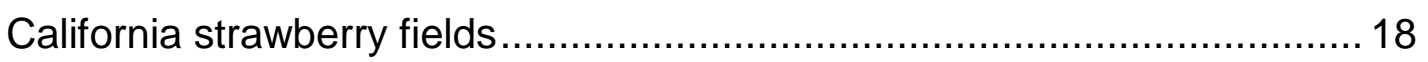

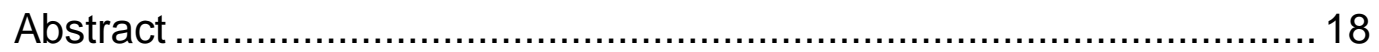

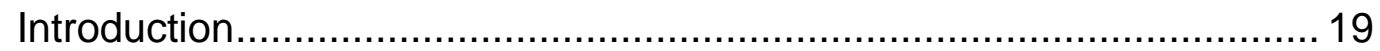

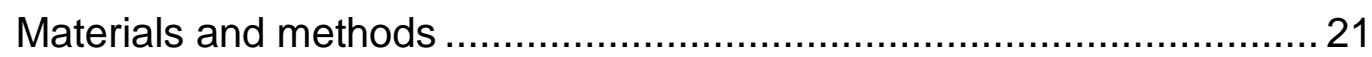

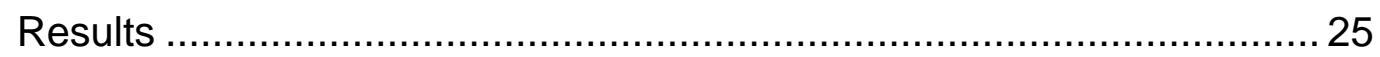

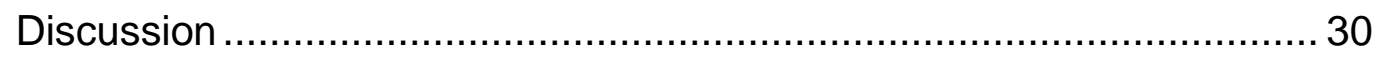

3 First Report of Botrytis mali Causing Gray Mold on Strawberry in

California. 
4 Development of Resistance in Field Populations of Botrytis cinerea

Following Exposure to Various Fungicide Programs................................... 38

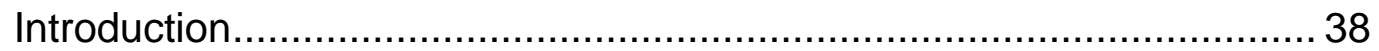

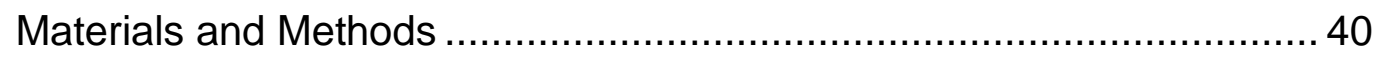

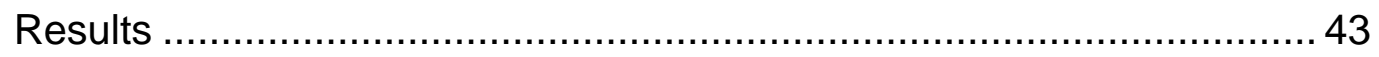

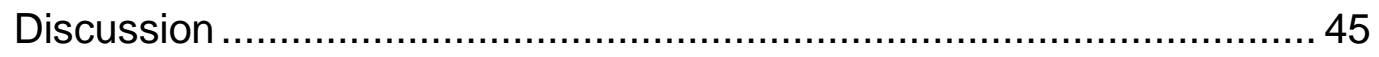

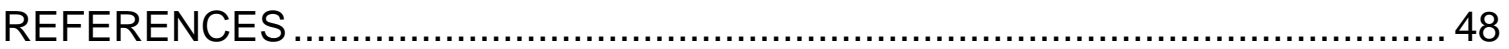




\section{LIST OF TABLES}

Table 1. Fungicides labeled for control of strawberry gray mold (caused by Page

Botrytis cinerea) in California.................................................... 13

Table 2. Discriminatory concentrations and media used in the mycelial growth assay to monitor resistance in isolates of Botrytis cinerea........................23

Table 3. Field trial fungicide treatments evaluated for resistance response in

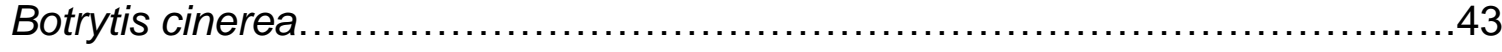




\section{LIST OF FIGURES}

Page

Fig. 1. Total 2017 strawberry fruit production in the United States by fruit weight (adapted from USDA-NASS 2017) ....................................

Fig. 2. The lifecycle of Botrytis cinerea including various plant diseases (Adapted from Agrios 2005).

Fig. 3. Early-season (white) and late-season (black) frequencies of resistance to ten active ingredients with isolates of Botrytis cinerea collected in conventional fields of the Southern $(n=229)$, Central $(n=165)$, and Northern $(n=308)$ strawberry growing districts of California. Fewer isolates were tested for resistance to pyraclostrobin in the Southern $(n=120)$, Central $(n=97)$ and Northern $(n=188)$ districts. Statistical significance of frequency of resistance between sampling times is represented by an asterisk $\left(^{*}\right)(p<0.05) \ldots \ldots \ldots \ldots \ldots . .26$

Fig. 4. Average number of chemical class resistances (CCR) of Botrytis cinerea isolates collected early- and late-season from conventional $(n=405)$ and organic $(n=103)$ California strawberry fields. Error bars are standard error of the means. Bars with different letters are significantly different according to a post-hoc Tukey's honest significant difference test $(\alpha=0.05) \ldots . .27$

Fig. 5. Early-season $(n=71)$ and late-season $(n=334)$ frequencies of chemical class resistance (CCR) phenotypes from Botrytis cinerea isolates collected in conventional fields of the Southern, Central, and Northern strawberry growing districts of California.

Fig. 6. Average number of applications per season of active ingredients labeled for gray mold of strawberry in 32 California conventional strawberry fields in 2016. Error bars are standard error of the means. Bars with different letters are significantly different according to a post-hoc Tukey's honest significant difference test $(\alpha=0.05)$

Fig. 7. Incubated strawberry fruit (cultivar Monterey) six days post-inoculation with Botrytis cinerea and Botrytis mali. Top row: top view. Bottom row: side view

Fig. 8. Frequencies of resistance of Botrytis cinerea to boscalid (top), fenhexamid (middle), and fludioxonil (bottom) observed in plots of strawberries treated with repeated applications of fungicides at five collection points in the trial. Collections timings: (I) one day before first fungicide application, (II) six days after third fungicide application, (III) six days after sixth fungicide application, (IV) 27 days after sixth fungicide application, and (V) 48 days after sixth fungicide application. Statistical significance of frequency of resistance 
between I and III is represented by an asterisk $\left({ }^{*}\right)$, and III and V by a double

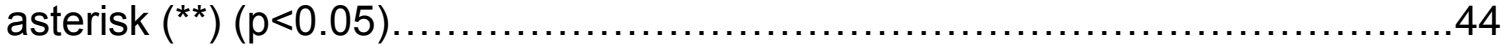




\section{CHAPTER 1}

\section{Literature Review}

\section{Introduction}

California produced $84 \%$ of the $\$ 2$ billion United States strawberry crop in 2017 (USDA-NASS 2017). The Southern (Irvine and Ventura County), Central (Santa Maria), and Northern (Salinas and Watsonville) strawberry growing districts contain 29,33 , and $36 \%$ of California's strawberry acreage, respectively (USDA-NASS 2016). Disease and insect pressures threaten strawberry production. One of these destructive strawberry pathogens is Botrytis cinerea Pers.:Fr., the causal agent of gray mold (Williamson et al. 2007). It is challenging to find effective and economic ways to combat pathogens like $B$. cinerea. Cultural methods can greatly reduce disease pressure, but there is very low tolerance for crop losses in strawberry production because of the crop's high value. Thus, fungicides are used to reduce losses due to gray mold. However, the use of any pesticide creates a selection pressure for resistant or insensitive individuals that will shift the population toward a greater concentration of resistant members (Deising et al. 2008). B. cinerea is a prime example of a high-risk pathogen for fungicide resistance. This literature review will discuss strawberry production in California, gray mold of strawberry, and fungicide resistance.

\section{The Strawberry}

History and Biology. Wild strawberries have been collected and cultivated for thousands of years, with the first references of strawberries found in poems from the Augustan period (63 BC to 19 AD). Many species of wild 
strawberries are native to temperate zones all over the world. The modern cultivated strawberry is a hybrid that arose from accidental crosses between a strawberry native to Chile (Fragaria chiloensis) and a strawberry native to Eastern North America (Fragaria virginiana). Antoine Nicolas Duchesne was the first botanist to describe the cross, dubbing it Fragaria $\times$ ananassa, in 1766 (Darrow 1966).

Botanically, strawberries are aggregate accessory fruit, where what is commonly called the "fruit" is an enlarged receptacle, while the "seeds" are individual fruit called achenes. An achene is a small dry fruit that contains a single seed. Strawberries are herbaceous plants that have trifoliate leaves and readily propagate through stolon (runner) production. They are naturally perennial plants, but in California, strawberries are primarily cultivated as an annual crop due to higher yields and lower disease and pest pressures in the first year (Hancock 1999; Strand 2008).

The California Strawberry Industry. California is the top producer of strawberries in the United States followed by Florida (Fig. 1). The vast majority of California's strawberry fruit is produced within three districts: Southern (Irvine and Ventura County), Central (Santa Maria), and Northern (Salinas and Watsonville). Cultural practices such as bed shape, irrigation, mulch color, and pest management are very similar within a region but can vary between them (Strand 2008). In California, there are two planting times during the year. Most acreage is planted in fall (fall-planted), while some acreage is planted early summer (summer-planted) (CSC 2017). 


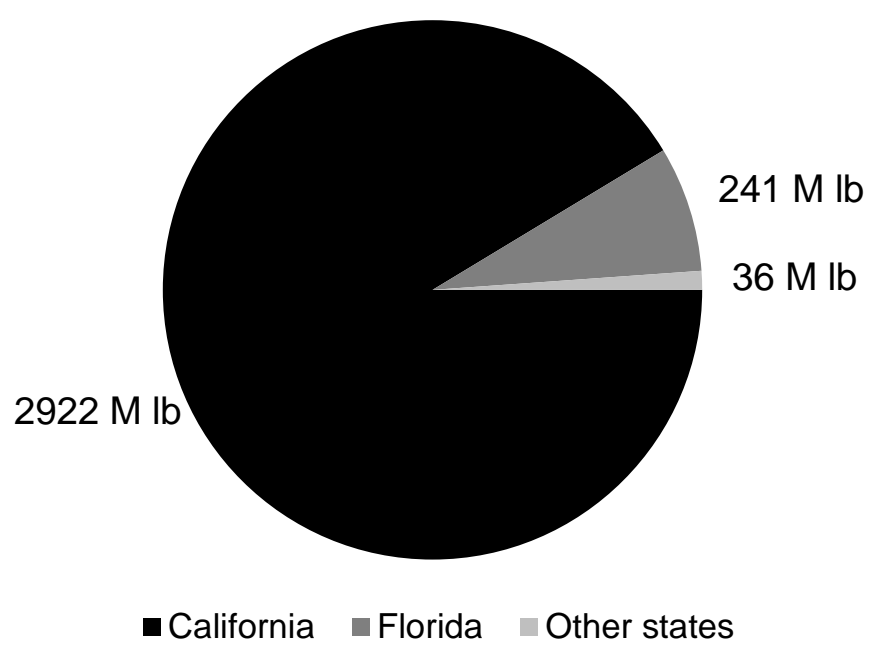

Fig. 1. Total 2017 strawberry fruit production in the United States by fruit weight (adapted from USDA-NASS 2017).

The Season. Strawberry plants begin their production cycle as runners in strawberry nurseries produced from mother plants. Once runners set roots and produce leaves, they become "daughter" plants. Daughter plants are mowed to remove leaves, dug with roots intact, separated, and shipped to growers for planting in boxes containing 800 to 1500 "bare root" plants per box. Nurseries strive to produce transplants free of pathogens such as Colletotrichum acutatum and Xanthomonas fragariae. Fruit production fields can be fumigated to control soil-borne pathogens. Beds are raised with buried drip irrigation. Plastic mulch is laid over the beds, and plant holes are punched in the plastic and the soil beneath. Strawberry plants are transplanted by hand and intermittently overhead irrigated for about one month before changing to drip irrigation. During the harvest portion of the season (5 to 6 month duration), the management of various pathogens and pests is accomplished by cultural methods and foliar applications of pesticides. Most pesticides applied during the harvest period have a short re- 
entry and post-harvest interval, because strawberry plants are constantly maintained and harvested. After harvest, pallets of fresh strawberries are forcedair cooled as soon as possible (usually less than 2 hours after harvest) to maximize shelf life (Strand 2008).

\section{Gray Mold of Strawberry}

Gray mold of strawberry, also known as Botrytis gray mold or Botrytis fruit rot, is caused primarily by Botrytis cinerea. Recently, gray mold was found to be also caused by Botrytis caroliniana, Botrytis fragariae, Botrytis mali, and Botryotinia ricini (Amiri et al. 2016; Dowling et al. 2017; Fernández-Ortuño et al. 2012; Shaw et al. 2016). These other Botrytis species are morphologically similar and are easily mistaken for B. cinerea; however, they may differ in competitiveness and sensitivity to various fungicides (Cosseboom et al. 2018; Dowling et al. 2017; Leroux et al. 2002). Although gray mold can be caused by these other Botrytis species, B. cinerea is considered responsible for the majority of symptomatic fruit. B. cinerea is also a pathogen to many crops (e.g., roses, lettuce, and apples) and able to infect many types of plant tissue (e.g., leaves, stems, bulbs, fruit, and flowers) (Fig. 2). 


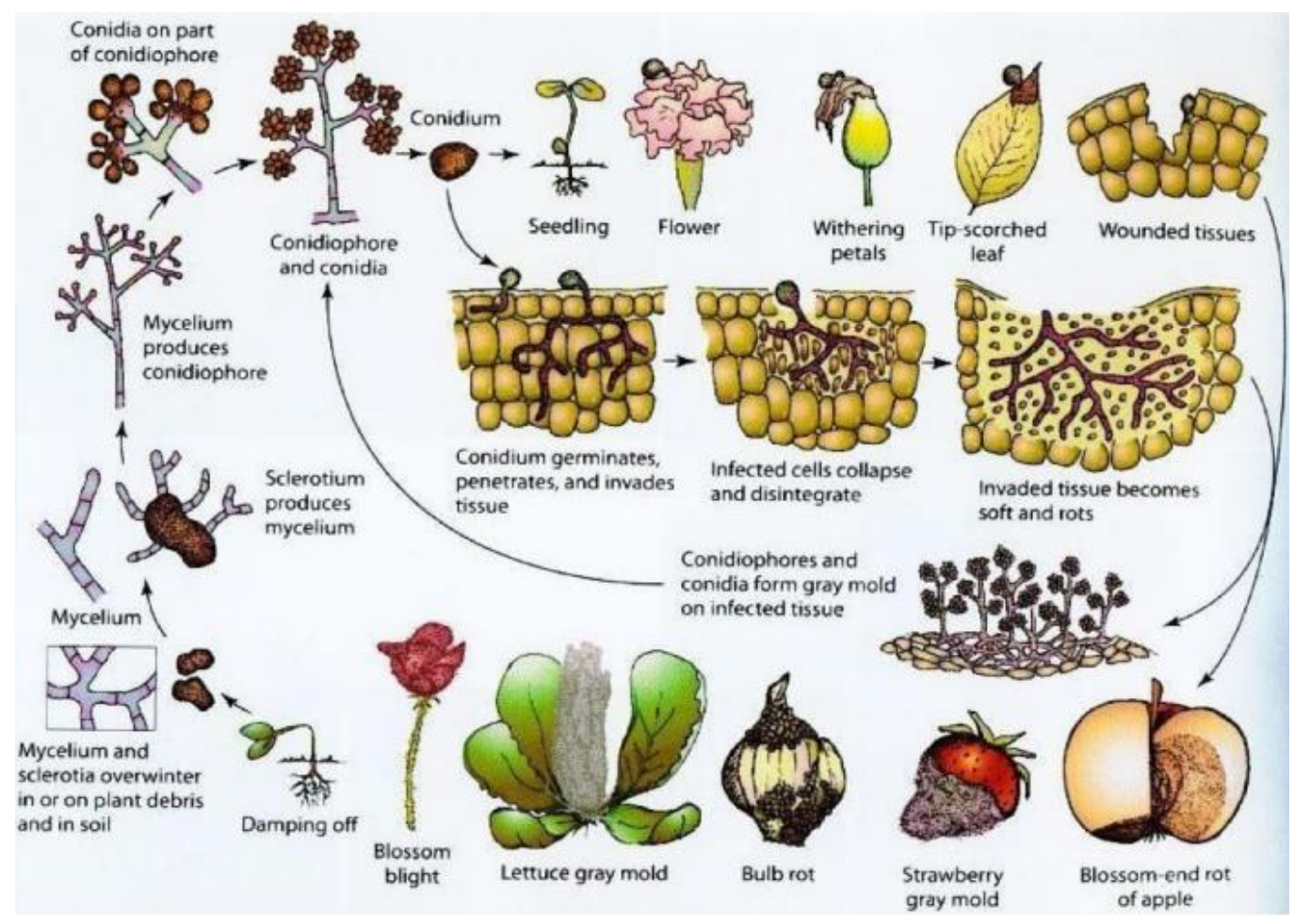

Fig. 2. The lifecycle of Botrytis cinerea including various plant diseases (Adapted from Agrios 2005).

Conidial spores of $B$. cinerea are disseminated primarily by wind, but can also be dispersed by splashing rain (Fitt et al. 1985; Jarvis 1962). The pathogen primarily infects by the way of germinated conidia through sensitive tissue like stamens and petals or through damaged cells. B. cinerea can infect newlyopened strawberry flowers, then become quiescent as resting mycelium until the fruit is mature or damaged (Bristow et al. 1986; Prusky 1996). Appropriate wetness duration and temperature is key to infection of flowers and fruit. Infection was almost certain with a wetness duration of over 24 hours and an ambient temperature within $15^{\circ}-25^{\circ} \mathrm{C}$. (Bulger et al. 1987). Ideal environmental conditions seem to allow $B$. cinerea to infect and deteriorate plant parts regardless of whether they are sensitive or damaged. Weather-based infection models have 
been based on temperature and wetness duration (MacKenzie and Peres 2012). The fungus can repeat its lifecycle by sporulating from infected tissue, producing conidiophores and conidia (Fig. 2) (Holz et al. 2004). B. cinerea can also survive as mycelium or sclerotia on decaying matter such as senescent leaves on the plant or in the furrow (Strømeng et al. 2009; Williamson et al. 2007). These dead leaves can be a source of new viable spores for the next season (Braun and Sutton 1987). Temperature and wetness duration is key in conidial sporulation from this dead tissue, as well as infection of plant parts besides the flower (SosaAlvarez et al. 1995).

Management. Management of gray mold of strawberry falls into three categories: biological, cultural, and chemical. The University of California Division of Agriculture and Natural Resources promotes an ecosystem-based strategy called Integrated Pest Management (IPM) (Strand 2008). The IPM strategy considers biological and cultural methods of pest management first, before applying conventional pesticides (Farrar et al. 2016). In the case of gray mold, biological and cultural methods become exhausted when the environment is favorable for the pathogen. These conditions render fungicides as the most effective option. Since the introduction of modern fungicides in the 1960's, management of gray mold has relied primarily upon foliar applications of fungicides at regular intervals (Delp 1988; Strand 2008). The three categories of management for strawberry gray mold are discussed in further detail below.

Cultural Management. Growers can use cultural methods to alter environmental conditions to prevent gray mold (Legard et al. 2000). Free 
moisture touching plant tissues and high humidity aids infection of strawberries by B. cinerea (Bulger et al., 1987). Fruit and above-ground plant parts can be prevented from contacting wet soil by using buried drip irrigation, plastic mulch laid over the beds, and beds shaped to allow excess water to run off the bed (Strand 2008). Moreover, plastic tunnels can protect plants from most rain and hail events as well as increase ambient temperature, allowing the environment to dry more quickly. In Florida and Ontario, tunnels have reduced the incidence of gray mold compared to an open field (Burlakoti et al. 2013; Xiao et al. 2001). Increased plant spacing to increase airflow reduced the incidence of gray mold, but also reduced total yield per acre (Legard et al. 2000). Strawberry cultivars with large bushy plant architecture or unpruned plants can reduce coverage of foliar fungicide applications as well as restrict airflow (Strand, 2008). Different cultivars of strawberry also have varying levels of susceptibility to gray mold (Legard et al. 2000; Seijo et al. 2008).

Besides modifying the pathogen's environment, targeting sources of $B$. cinerea inoculum is also an effective cultural management strategy. Infected plant debris in the field from the previous season can be a source of viable inoculum (Strømeng et al. 2009). Field sanitation by removing unmarketable fruit and senescent plant parts decreases the amount of $B$. cinerea inoculum in the field. However, this has not been shown to have a positive impact on yield (Mertely et al. 2000). Other cultural methods such as fertilization or ultraviolet radiation can also affect the incidence of gray mold (Janisiewicz et al. 2016; Nicot 
et al. 1996). Specific nutrient levels may boost the strawberry plant's defense response to B. cinerea infection (Abro et al. 2013; Yermiyahu et al. 2006).

Chemical \& Biological Management. Chemical control is more effective and relatively inexpensive compared to many cultural methods of gray mold management (Mertely et al. 2000). Fungicides are usually applied to foliage of strawberry plants with a tractor-pressurized spray boom with multiple nozzles targeting plants within each bed. Fungicide applications are more effective during the open flower stage as opposed to the juvenile or mature fruit stage; however, strawberry plants constantly produce new flowers (Mertely et al. 2002).

Therefore, growers in California make applications on a calendar-based system (every 7 to 14 days) (Cosseboom et al. 2017).

Organic approved products have limited efficacy against $B$. cinerea and are not used often for gray mold management (Adaskaveg et al. 2017). Organic products include plant extracts, essential oils, inorganic compounds, and living microorganisms (Palmer et al. 1997; Wilson et al. 2015). There are five living organism strains currently labeled for gray mold, and several other species have been evaluated and found to have activity against Botrytis (Boff et al. 2002; Cheng et al. 2012; Köhl et al. 2000; Köhl and Molhoek 2001).

Postharvest management. Pre-harvest cultural and chemical management methods can greatly impact the post-harvest development of gray mold. Fruit harvested for fresh market should be removed from the field and cooled as soon as possible. Fruit kept cool delays development of gray mold, although B. cinerea can still grow at $0^{\circ} \mathrm{C}$ (Elad et al. 2004). Just like in the field, 
free-moisture is an important factor in post-harvest gray mold development. Therefore, strawberries should be kept as dry as possible until consumption. Strawberries are also transported with a modified atmosphere (elevated CO2) to prolong shelf-life (Smith 1992).

\section{Fungicide Resistance}

Similar to antibiotic resistance in the medical arena, fungicide resistance in agriculture has become a major problem over the last few decades. Fungicide resistance is a stable, inheritable change in a fungal population resulting in reduced efficacy of a fungicide. Most fungicide resistance issues are the result of genetic point mutations that cause a reduction or loss in efficacy. Fungi can also gradually become resistant with mutations that cause them to degrade, sequester, or excrete fungicides or by overexpression of the target protein (Ma and Michailides 2005). Resistance conferring mutations occur naturally in fungal populations in small frequencies. These resistant individuals have a competitive advantage if there is selection pressure (fungicide) that allows them to thrive when other members of the population cannot. The frequency of selection events (fungicide applications), the mode of action of the active ingredient, the ability of the fungus to proliferate, and its ability to implement genetic changes will determine how quickly resistance develops within a population (Leroux et al. 2002; Olson-Manning et al. 2013). In agriculture, two of these factors can be controlled by keeping fungal pathogen population size as small as possible, and by reducing selection pressure (reducing fungicide usage). However, the application of fungicides is often the only way to reduce disease incidence. 
Fortunately, many types of fungicides exist that attack fungi in different ways. Site-specific fungicides have a particular site-of-action that inhibits a critical function of a fungus. For example, thiophanate-methyl prevents microtubule formation, while fluopyram inhibits the electron transport chain in respiration. These fungicides are typically very effective and non-toxic, but resistance is possible. A mutation that confers resistance to fluopyram will not confer resistance to thiophanate-methyl and vice versa. Therefore, these fungicides used in rotation will spread out the selection pressure over two sites rather than just one if only one fungicide was used consecutively (Johnson et al. 1994). Multisite fungicides (e.g., captan and thiram) attack a fungus at multiple sites. These fungicides are usually less effective than site-specific fungicides, however resistance to them has not been reported (Deising et al. 2008).

The simplest way to reduce selection pressure is to use fewer applications of site-specific fungicides, however this may sacrifice crop yields. The Fungicide Resistance Action Committee (FRAC) promotes sustainable ways to use fungicides while eliminating or reducing resistance development. They have placed fungicides into groups, called FRAC codes, based on previously observed cross resistance behavior (FRAC 2017). Rotating among these fungicide groups reduces the risk of resistance development (Kable and Jeffery 1980; Deising et al. 2008). Tank mixing a high-resistance-risk fungicide (e.g., site-specific) with a low-resistance-risk fungicide (e.g., multisite) may prolong the efficacy of the highrisk fungicide (van den Bosch et al. 2014). The mutation that confers resistance to a fungicide may also include a fitness penalty (Chen et al. 2016). A fitness 
penalty may allow a resistant population to revert to sensitive in the absence of selection pressure.

Fungicide resistance in Botrytis cinerea. $B$. cinerea is prone to resistance due to its genetic variability, high fecundity, short life cycle, and wide host range (Leroux et al. 2002; Olson-Manning et al. 2013). The first report of $B$. cinerea fungicide resistance was reported only two years after the introduction of benomyl, the first site-specific fungicide used for $B$. cinerea (Bollen and Scholten 1971). Grabke and Stammler observed that 199 isolates collected on the same day in a strawberry field had over 24 different combinations of resistance conferring mutations (Grabke and Stammler 2015).

Multi-fungicide resistant isolates are a rising concern (Konstantinou et al. 2015; Raposo et al. 1996), and strains resistant to seven chemical classes of fungicides have been found in the Eastern United States (Fernández-Ortuño et al. 2015). Populations were found to accumulate resistance to multiple fungicides, one at a time, in a stepwise fashion ( $\mathrm{Li}$ et al. 2014). Populations have also been found to contain members with a multi-drug resistant (MDR) phenotype, where a single mutation confers resistance to multiple chemical classes of fungicides (Chen et al. 2016). Resistance monitoring programs have been conducted to measure the general amount of resistance to multiple fungicides over broad areas. These studies have been conducted for $B$. cinerea in strawberry in California (Mercier et al. 2010; Pokorny et al. 2016), Southeastern United States (Amiri et al. 2013; Fernández-Ortuño et al. 2014), 
Spain (Fernández-Ortuño et al. 2016), Greece (Konstantinou et al. 2015), Germany (Weber 2011), and China (Fan et al. 2017).

Resistance surveys in strawberries have reported widespread resistance to all chemical classes. This dictates the need for new and improved resistance management strategies. Calendar-based spray programs can result in 15 to 20 applications per season (Cosseboom et al. 2017; Legard et al. 2001). A weatherbased infection warning system reduced the number of fungicide applications per season by up to $47 \%$ while maintaining statistically similar yields compared to a traditionally treated field (MacKenzie and Peres 2012; Pavan et al. 2011). Strawberry nurseries apply similar chemical classes for the prevention of anthracnose crown rot, which may be selecting for resistance in $B$. cinerea. Cooperation with strawberry nurseries may reduce the introduction of resistant phenotypes into fruit production fields. Replacing site-specific with multisite fungicides at times of low disease pressure can also decrease selection pressure for resistance to the few effective chemical classes (Hu et al. 2018; Oliveira et al. 2017).

Site-specific active ingredients labeled for gray mold of strawberry are within eight FRAC codes (chemical classes): 1 [methyl benzimidazole carbamate (MBC)], 2 [dicarboxamide (DC)], 7 [succinate dehydrogenase inhibitor (SDHI)], 9 [anilinopyrimidine (AP)], 11 [quinone outside inhibitor (Qol)], 12 [phenylpyrrole (PP)], 17 [hydroxyanilide (HA)], and 19 (polyoxin). These chemical classes each select for unique genetic mutations, which affect their resistance-risk and the associated fitness costs. Each chemical class is expanded upon below. 
Table 1. Fungicides labeled for control of strawberry gray mold (caused by Botrytis cinerea) in California.

\begin{tabular}{|c|c|c|c|}
\hline \multicolumn{2}{|c|}{ Example trade name Active ingredient(s) } & \multicolumn{2}{|c|}{ FRAC* } \\
\hline Topsin & Thiophanate-methyl & 1 & \\
\hline Rovral & Iprodione & 2 & \\
\hline Fontelis & Penthiopyrad & 7 & \\
\hline Kenja 400 & Isofetamid & 7 & \\
\hline Luna Tranquility & Fluopyram + pyrimethanil & 7 & 9 \\
\hline Luna Sensation & Fluopyram + trifloxystrobin & 7 & 11 \\
\hline Merivon & Fluxapyroxad + pyraclostrobin & 7 & 11 \\
\hline Pristine & Boscalid + pyraclostrobin & 7 & 11 \\
\hline Scala & Pyrimethanil & 9 & \\
\hline Switch & Cyprodinil + fludioxonil & 9 & 12 \\
\hline Intuity & Mandestrobin & 11 & \\
\hline Elevate & Fenhexamid & 17 & \\
\hline CaptEvate & Fenhexamid + captan & 17 & M4 \\
\hline Ph-D & Polyoxin-D & 19 & \\
\hline Thiram & Thiram & M3 & \\
\hline Captan & Captan & M4 & \\
\hline Double Nickel LC/55 & Bacillus amyloliquefaciens & 44 & \\
\hline Serenade ASO & Bacillus subtilis & 44 & \\
\hline Regalia & Extract of Reynoutria sachalinensis & 46 & \\
\hline Trilogy & Neem Oil & 46 & \\
\hline Fracture & Banda de Lupinus albus doce & BM 01 & \\
\hline Prev-Am Ultra & Sodium tetraborate decahydrate & $N^{* *}$ & \\
\hline Actinovate AG/SP & Streptomyces lydicus & NL & \\
\hline Oxidate 2.0 & $\mathrm{H}_{2} \mathrm{O}_{2}+$ Peroxyacetic acid & NL & \\
\hline BotryStop & Ulocladium oudemansii & NL & \\
\hline Botector & Aureobasidium pullulans & NL & \\
\hline \multicolumn{4}{|c|}{$\begin{array}{l}\text { Site-specific mode of action; conventional use only } \\
\text { Multisite mode of action; conventional use only } \\
\text { OMRI approved }\end{array}$} \\
\hline
\end{tabular}

Anilinopyrimidines (AP). These fungicides inhibit methionine biosynthesis, however the exact mechanism of action is not known. Highly resistant isolates are common, and the molecular basis of this resistance is also unknown (Li et al. 2014). Slight insensitivity can be caused by overexpression of ABC-transporters (MDR phenotypes) (Leroux et al. 2002). High resistance was found to be a genetically stable trait, and no significant fitness cost was related to 
resistance (Bardas et al. 2008). This chemical class contains the active ingredients cyprodinil and pyrimethanil. Complete cross-resistance between cyprodinil and pyrimethanil has been observed (Myresiotis et al. 2007).

Dicarboximides (DC). DCs affect osmoregulation by interfering with the osmotic signal transduction pathway. Multiple mutations within the BcOS-1 gene, also known as Bos1 or Daf1, confer resistance (Cui et al. 2004). Crossresistance between DCs and PPs has been observed in laboratory mutants but not from field isolates (Faretra and Pollastro 1993; Leroux et al. 1999; Weber 2011). DC resistance has been shown to be unstable in laboratory and in field trials (Hunter et al. 1987; Johnson et al. 1994; Raposo et al. 2000; Yourman et al. 2001). Iprodione is the only DC currently labeled for use in California; however, a label restriction limits use in strawberries to one application before the first bloom. This nearly eliminates use of this fungicide in fruit producing fields since most fungicides are applied during the period of fruit harvesting.

Phenylpyrroles (PP). The mode of action of PPs is not fully understood, however, it is thought to be similar to DCs (Furukawa et al. 2012). Mutations within multiple domains of Bos1 were related with highly resistant field isolates of B. cinerea. PP resistant strains of $B$. cinerea and other fungal species show reduced fitness compared to sensitive strains ( $\mathrm{Li}$ and Xiao 2008; Ren et al. 2016; Ziogas et al. 2005). The reduced fitness of resistant strains may explain why resistant isolates were rarely found from widespread screening of strawberry fields (Amiri et al. 2013; Fernández-Ortuño et al. 2014). Fludioxonil is the only PP fungicide labeled for gray mold of strawberry and the first fludioxonil resistant 
strain from a strawberry field was reported in 2013 (Fernández-Ortuño et al. 2013).

Polyoxins. Polyoxins prevent chitin formation in the cell wall by inhibiting chitin synthetase (Endo et al. 1970). Reduced sensitive isolates have been found prior to the introduction of these fungicides, but highly resistant isolates have not been found (Mamiev et al. 2013). It is unclear whether field rates of a polyoxin fungicide can control reduced sensitive isolates, however reduced sensitive isolates may be less fit (Dowling et al. 2016). Polyoxin D zinc salt is currently the only polyoxin labeled for use on gray mold of strawberry in the United States and has been available since 2012 .

Quinone outside inhibitors (Qol). Fungicides within this chemical class inhibit mitochondrial respiration by binding to complex III of the electron transport chain (Bartlett et al. 2002). Primarily one mutation (G143A) within the cytochrome b gene has been associated with resistance to Qols (Fernández-Ortuño et al. 2008; Leroux et al. 2010). Resistance to Qols does not appear to entail a significant fitness cost (Karaoglanidis et al. 2010; Veloukas et al. 2014). Resistance to Qols is widespread among Botrytis from strawberry (Li et al. 2014; Leroux et al. 2010), perhaps partially due to non-target selection because some Qol fungicides are labeled for powdery mildew and not gray mold. Azoxystrobin, mandestrobin, pyraclostrobin, and trifloxystrobin are all Qols labeled for use in strawberries.

Methyl benzimidazole carbamates (MBC). These fungicides bind to tubulin and inhibit microtubule formation (Leroux et al. 2002). Mutations within 
the $\beta$-tubulin gene have been associated with resistance in B. cinerea (Luck and Gillings 1995; Ma and Michailides 2005). There does not appear to be a significant fitness cost associated with resistance to MBCs (Johnson et al. 1994; Yourman et al. 2001). These were the first site-specific fungicides used against B. cinerea, and they were used almost exclusively after their introduction, quickly leading to a high level of resistance (Chaube and Pundhir 2005). In 1990 and 2008, 77 and $90 \%$ of isolates collected from Oregon and California strawberry fields were found to be resistant to MBCs, respectively (Johnson et al. 1994; Mercier et al. 2010). Thiophanate-methyl is the only MBC labeled for use in strawberries.

Hydroxyanilides (HA). Fungicides within this chemical class inhibit C4 demethylation, a critical factor in the biosynthesis of an important structural sterol in fungal membranes (Debieu et al. 2001). Mutations within the erg27 gene were found to confer resistance to the HA fenhexamid and these mutations have been associated with a fitness cost (Billard et al. 2012; Fillinger et al. 2008; Grabke et al. 2013; Saito et al. 2014). Resistance to fenhexamid in strawberries is common and widespread in the United States (Li et al. 2014; Pokorny et al. 2016). Fenhexamid is currently the only HA labeled for gray mold of strawberry.

Succinate dehydrogenase inhibitors (SDHI). SDHIs target succinate dehydrogenase (SDH), which is a key member (complex II) of the mitochondrial electron transport chain (White and Georgopoulos 1991). SDH consists of four subunits called SdhA, SdhB, SdhC, and SdhD. Mutations within SdhB and SdhD have been associated with resistance to the SDHIs in Botrytis (Fernández- 
Ortuño et al. 2017; Leroux et al. 2010). Field-level resistance varies between the different SDHI fungicides according to the mutation within the succinate dehydrogenase gene. A single mutation may confer resistance to one or more SDHI active ingredients (Hu et al. 2016b). Resistance to SDHIs is widespread throughout $B$. cinerea populations in strawberry, but has been in low to moderate frequencies (Fernández-Ortuño et al. 2014, 2016). Studies conflict on whether a fitness cost is associated with resistance to SDHls, however it may depend upon the mutation (Lalève et al. 2014; Veloukas et al. 2014; Yin et al. 2011). Boscalid, fluopyram, fluxapyroxad, isofetamid, and penthiopyrad are all SDHI fungicides labeled for use on gray mold of strawberry in the United States.

\section{Conclusion}

The United States strawberry industry has grown immensely since the crop was first introduced to the American colonies in the $18^{\text {th }}$ century (Darrow 1966). California produces the majority of strawberry fruit in the United States both because of more acreage and because of higher marketable production per acre than other states due to a longer season (USDA-NASS 2016, 2017).

Producing a valuable crop like strawberries at a high quality with minimal losses requires the crop to be protected from pathogens and pests like $B$. cinerea. While chemical control of this disease is the most cost effective management method, rising resistance to these fungicides may dramatically reduce their effective life. The research discussed in the following chapters will advance understanding of fungicide resistance and will aid resistance management decisions in California strawberries. 


\section{CHAPTER 2}

\section{Within-season shift in fungicide resistance profiles of Botrytis cinerea in California strawberry fields}

As submitted: Cosseboom, S. D., Ivors, K. L., Schnabel, G., Bryson, P. K., and Holmes, G. J. 2018. Within-season shift in fungicide resistance profiles of Botrytis cinerea in California strawberry fields. Plant Dis.

S. D. Cosseboom and K. L. Ivors, Department of Horticulture and Crop Science, California Polytechnic State University, San Luis Obispo, CA 93407; G. Schnabel and P. K. Bryson Department of Plant and Environmental Sciences, Clemson University, Clemson, SC 29634; and G. J. Holmes, Cal Poly Strawberry Center, San Luis Obispo, CA 93407.

\section{Abstract}

Sensitivity of Botrytis cinerea to seven fungicide chemical classes was determined for 888 isolates collected in 2016 from 47 California strawberry fields. Isolates were collected early-season (minimum fungicide exposure) and lateseason (maximum fungicide exposure) from the same planting block in each field. Resistance was determined using a mycelial growth assay and variable frequencies of resistance were observed to each fungicide at both sampling times (early-season \%, late-season \%): boscalid $(12,35)$, cyprodinil $(12,46)$, fenhexamid $(53,91)$, fludioxonil $(1,4)$, fluopyram $(2,7)$, iprodione $(25,8)$, 
isofetamid $(0,1)$, penthiopyrad $(8,25)$, pyraclostrobin $(77,98)$, and thiophanatemethyl $(81,96)$. Analysis of number of chemical class resistances (CCR) revealed an increasing shift in CCR from the early- to late-season. Phenotypes of 40 isolates that were resistant or sensitive to different chemical classes were associated with presence or absence of mutations in target genes. Fungicide resistance phenotypes determined in the mycelial growth assay closely matched $(93.8 \%)$ the genotype observed. Previously described resistance-conferring mutations were found for each gene. A survey of fungicide use from 32 of the sampled fields revealed an average of 15 applications of gray mold labeled fungicides per season at an average interval of 12 days. The most frequently applied fungicides (average number of applications during the 2016 season) were captan (7.3), pyraclostrobin (2.5), cyprodinil (2.3), fludioxonil (2.3), boscalid (1.8), and fenhexamid (1.4). Multifungicide resistance is widespread in California. Resistance management tactics that reduce selection pressure by limiting fungicide use, rotating among FRAC codes, and mixing/rotating site-specific fungicides with multisite fungicides need to be improved and implemented.

\section{Introduction}

When environmental conditions are favorable for Botrytis cinerea Pers.:Fr., the causal agent of strawberry gray mold, fungicides are the most effective management method (Mertely et al. 2000). Over 20 fungicide applications can be made per season for prevention of this disease (Legard et al. 2001). Populations of $B$. cinerea in strawberry fields with multiple chemical class resistances (CCR) are a rising concern (Fernández-Ortuño et al. 2014; 
Konstantinou et al. 2015; Saito et al. 2016). Multiple fungicide applications per season may be selecting for increasingly resistant populations of $B$. cinerea (Adaskaveg and Gubler 2006).

Currently, all site-specific fungicides labeled for gray mold of strawberry in the United States belong to eight chemical classes. Fungicide Resistance Action Committee (FRAC) codes 1, 2, 7, 9, 11, 12, 17, and 19 represent the methyl benzimidazole carbamate (MBC), dicarboxamide (DC), succinate dehydrogenase inhibitor (SDHI), anilinopyrimidine (AP), quinone outside inhibitor (Qol), phenylpyrrole (PP), hydroxyanilide (HA), and polyoxin chemical classes, respectively. Active ingredients are placed into FRAC codes according to their cross-resistance behavior (FRAC 2017). In the United States, B. cinerea isolates collected from strawberries have been reported to be resistant to fungicides within every chemical class except for the polyoxins (Dowling et al. 2016; Fernández-Ortuño et al. 2015). In strawberry fields within the southeastern United States, individual isolates of $B$. cinerea have been found to be resistant to up to seven chemical classes (7CCR) (Fernández-Ortuño et al. 2015). Although $5 \mathrm{CCR}$ isolates have been found to be competitively disadvantaged compared to sensitive isolates, multi-CCR subpopulations likely persist because of high selection pressure from the frequent application of site-specific fungicides (Chen et al. 2016; Hu et al. 2016a).

Reports of extensive frequencies of resistance (>20\%) to APs, DCs, MBCs, Qols, and SDHIs in B. cinerea collected from strawberries in the Eastern United States demonstrate the necessity for the characterization of resistance 
levels within California, the leading strawberry producing state (FernándezOrtuño et al. 2014). Understanding the distribution and frequency of resistant phenotypes of $B$. cinerea in California will aid resistance management efforts. Previous studies in California strawberries showed that resistance to popular fungicides exists (Mercier et al. 2010; Pokorny et al. 2016) and that the frequency of resistance in a field population can change within a season (Adaskaveg and Gubler 2006). The objectives of this study were to determine (i) the frequency of fungicide resistance in the Southern (Ventura county), Central (San Luis Obispo and Santa Barbara counties), and Northern (Monterey and Santa Cruz counties) strawberry growing districts of California to active ingredients of seven currently registered chemical classes; (ii) shifts in fungicide sensitivity profiles within a production season; (iii) the genetic basis of resistance, and (iv) fungicide use during the same season.

\section{Materials and methods}

Isolate collection and characterization. In 2016, 888 bulk conidial isolates of $B$. cinerea were collected from 37 conventional and 10 organic strawberry fields dispersed throughout California's Southern (296 isolates), Central (200 isolates), and Northern (392 isolates) strawberry growing districts. Isolates were randomly collected from a 10-acre, fall-planted block in each field by brushing an individually wrapped, sterile applicator stick (Thermo Fisher Scientific, Waltham, MA) against a sporulating lesion of gray mold. If sporulating fruit could not be found in the field, green strawberry fruit were collected, surface sterilized for one minute in $10 \%$ bleach, and incubated until signs of gray mold 
appeared as described previously (Fernández-Ortuño et al. 2014). The same 10acre block in each field was sampled twice: early-season (zero to few fungicide applications; minimum fungicide exposure) and late-season (10 to 20 fungicide applications; maximum fungicide exposure). Approximately ten isolates were collected per field at each sampling time. To determine the species of each isolate, the NEP2 gene from 95 randomly selected isolates was amplified with primers capable of differentiating between three important causal agents: $B$. cinerea, Botrytis fragariae, and Botrytis mali (Dowling et al. 2017).

Mycelial growth assay. A discriminatory fungicide dose was used to differentiate sensitive from resistant isolates. Formulated products containing single active ingredients were used to create a unique growing medium for each active ingredient tested (Table 1). Fungicide dosages and growing media from previous studies were utilized (Fernández-Ortuño et al. 2014; Weber and Hahn 2011). Sterile toothpicks were used to transfer spores from each swab to the different fungicide amended media in wells of 24-well plates (Thermo Fischer Scientific, Waltham, MA). Plates were incubated at $22^{\circ} \mathrm{C}$ for 4 days and diametric colony growth was visually assessed in each well as: sensitive (S) for less than $20 \%$ diametric growth, and resistant $(R)$ for more than $20 \%$ diametric growth with respect to the $15 \mathrm{~mm}$-well. A subset of the collected isolates from conventional (71 early-season and 334 late-season) and organic fields (21 earlyseason and 82 late-season) were also tested for resistance to pyraclostrobin and characterized according to the number ( $\mathrm{n}$ ) of chemical classes they were resistant to (nChemical Class Resistance; nCCR). CCR in Botrytis populations is 
used to monitor the prevalence of multifungicide resistance (Chen et al. 2016;

Fernández-Ortuño et al. 2014). Conventional fields of the Northern, Central, and

Southern districts were represented by 120,97 , and 188 isolates, respectively.

Table 2. Discriminatory concentrations and media used in the mycelial growth assay to monitor resistance in isolates of Botrytis cinerea ${ }^{a}$

\begin{tabular}{llcl}
\hline Trade name & $\begin{array}{l}\text { Active ingredient } \\
\text { (FRAC code) }\end{array}$ & $\begin{array}{c}\text { Concentration }(\boldsymbol{\mu g} \\
\text { ai/ml) }\end{array}$ & Medium \\
\hline Non-amended & N/A & N/A & CZA \\
Vangard & Cyprodinil (9) & 4.0 & CZA \\
Scholar SC & Fludioxonil (12) & 0.5 & MEA \\
Elevate & Fenhexamid (17) & 50.0 & MEA \\
Rovral & Iprodione (2) & 10.0 & MEA \\
Topsin M & Thiophanate-methyl (1) & 100.0 & MEA \\
Cabrio & Pyraclostrobin (11) & 10.0 & MEA + SHAM at $100 \mu \mathrm{g} / \mathrm{ml}$ \\
Endura & Boscalid (7) & 75.0 & YBA* \\
Luna Privilege & Fluopyram (7) & 10.0 & YBA \\
Fontelis & Penthiopyrad (7) & 5.0 & YBA \\
Kenja & Isofetamid (7) & 5.0 & YBA \\
\hline
\end{tabular}

a Fungicide concentrations and media were previously described by Weber and Hahn 2011, FRAC = Fungicide Resistance Action Committee, CZA = CzapekDox agar medium, MEA = malt extract agar, SHAM = the alternative oxidase inhibitor salicyl hydroxamic acid, YBA = yeast bacto acetate agar; this media avoids the interference of sugars with the assay (Weber and Hahn 2011).

Molecular basis of resistance and isolate identification. The validity of the mycelial growth assay was vetted by comparing resistant phenotypes to the presence of variations in target genes or transcription factors of 40 representative isolates from all growing districts. Genomic DNA was extracted using a previously described method (Chi et al. 2009). The following target genes were screened for resistance-associated mutations: beta-tubulin gene, cytochrome b (cytb) gene, histidine kinase gene (bos1), keto-reductase gene (erg27), transcription factor $m r r 1$ gene, and $s d h B$ gene. Mutations within these genes are known to confer resistance to FRAC $1,11,2,17,12$, and 7 , respectively. We 
chose to sequence the beta-tubulin gene from 9 resistant and 2 sensitive isolates, the cytb gene from 10 resistant and 1 sensitive isolates, the bos 1 gene from 11 resistant and 1 sensitive isolates, the erg 27 gene from 8 resistant and 6 sensitive isolates, the mrr 1 gene from 3 resistant and 1 sensitive isolates, and the $s d h B$ gene from 16 resistant and 1 sensitive isolates. There was at least one isolate from each district represented for each gene. Previously published thermocycling protocols and primers were used for each gene (Amiri et al. 2014; Fernández-Ortuño et al. 2012; Grabke et al. 2013; 2014; Kretschmer et al. 2009; Leroch et al. 2013; Luck and Gillings 1995; Ma et al. 2007; Yin et al. 2011). PCR reactions were conducted in a total volume of $20 \mu \mathrm{L}$ and contained AccuPower Hotstart PCR PreMix (Bioneer Corp., Alameda, CA) and 0.2 $\mu$ L DNA. PCR products were electrophoresed for 1 hour at $100 \mathrm{~V}$ constant voltage on $1.0 \%$ agarose gel with TAE (Tris-acetate EDTA) buffer. The target site of FRAC 9 fungicides was unknown and therefore was not included.

Fungicide use survey. In California, all pesticide use is reported to the California Department of Pesticide Regulation by the Agricultural Commissioner offices in each county. In 2017, a public records request for 2016 pesticide use information was submitted to the Agricultural Commissioner offices in the counties of the Southern, Central, and Northern strawberry growing districts. Fungicide use data of products labeled for gray mold of strawberry in 32 of the sampled conventional fields was summarized by application interval and applications per season for each field. 
Statistical analysis. JMP software (version 12.1.0; SAS Institute, Cary, NC) was used to perform statistical analyses. An analysis of variance was used to compare the average CCR from early- and late-season sampling times from conventional and organic ranches. Multiple comparisons of average CCR were conducted using a post-hoc Tukey's honest significant difference (HSD) test. The relationship between the resistance observed and the sampling time for each fungicide treatment was compared using a Fisher's exact test and adjusted with a Bonferroni correction. A one-tailed two-sample t-test was used to compare the average CCR observed in the early-season to the late-season. For the fungicide usage data, the average applications per season of each active ingredient was square root transformed and analyzed by two-way analysis of variance with the explanatory variables of growing district and active ingredient. Multiple comparisons of fungicide usage means were conducted using a post-hoc Tukey's HSD test.

\section{Results}

Fungicide resistance profiles. In conventional fields, $90 \%$ of isolates were resistant to pyraclostrobin, $86 \%$ to thiophanate-methyl, $66 \%$ to fenhexamid, $26 \%$ to cyprodinil, $23 \%$ to boscalid, $15 \%$ to penthiopyrad, $14 \%$ to iprodione, $4 \%$ to fluopyram, $2 \%$ to fludioxonil, and $1 \%$ to isofetamid. Resistance frequencies were significantly different $(p<0.0001)$ between the early- and late-season for all active ingredients except fluopyram and isofetamid (Fig. 3). Frequencies of resistance varied from district to district and from field to field within the same district. Resistance to isofetamid was only observed in three isolates from the 
late-season sampling of the Northern district. A subset of 95 isolates

representing all districts were identified to be $B$. cinerea (94 isolates) and $B$. mali (1 isolate).

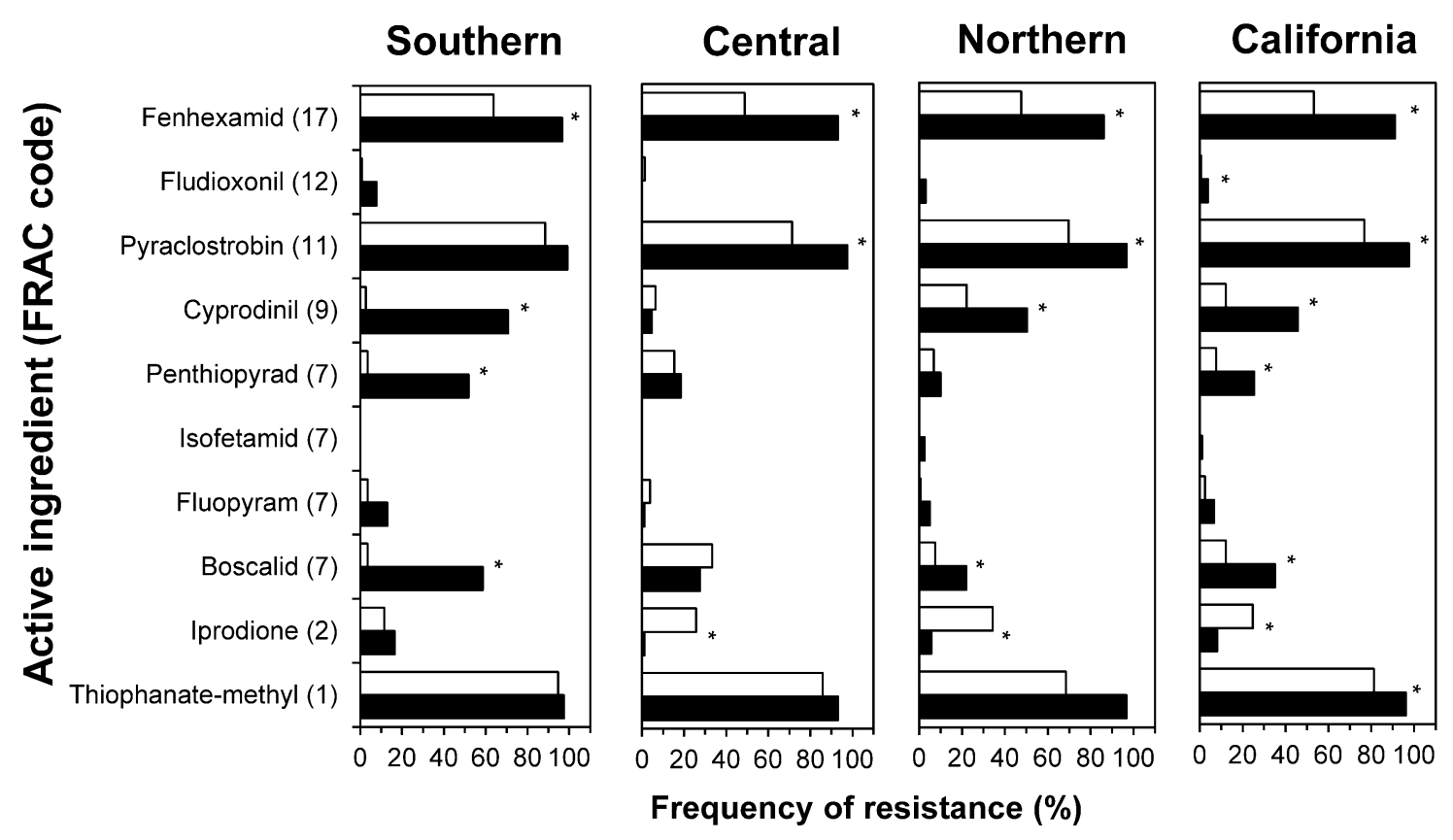

Fig. 3. Early-season (white) and late-season (black) frequencies of resistance to ten active ingredients with isolates of Botrytis cinerea collected in conventional fields of the Southern $(n=229)$, Central $(n=165)$, and Northern $(n=308)$ strawberry growing districts of California. Fewer isolates were tested for resistance to pyraclostrobin in the Southern $(n=120)$, Central $(n=97)$ and Northern $(n=188)$ districts. Statistical significance of frequency of resistance between sampling times is represented by an asterisk $\left(^{*}\right)(p<0.05)$.

Resistance phenotypes. The average CCR of isolates from late-season conventional fields was statistically higher than early-season conventional fields and organic fields at both sampling times (Fig. 4). From conventional fields, there were 45 distinct resistance patterns among the 405 isolates tested for resistance to all seven FRAC codes (including pyraclostrobin). The most common resistance pattern was resistance to fenhexamid, pyraclostrobin, and 
thiophanate-methyl. Consequently, the most common CCR phenotype was 3CCR both in the early-season and late-season collections. Populations had significantly higher CCR values in the late-season compared to the early-season $(F[102]=2.83, p$-value $=0.003)$. We only detected four $7 C C R$ isolates during the late-season and only from the Northern district (Fig. 5).

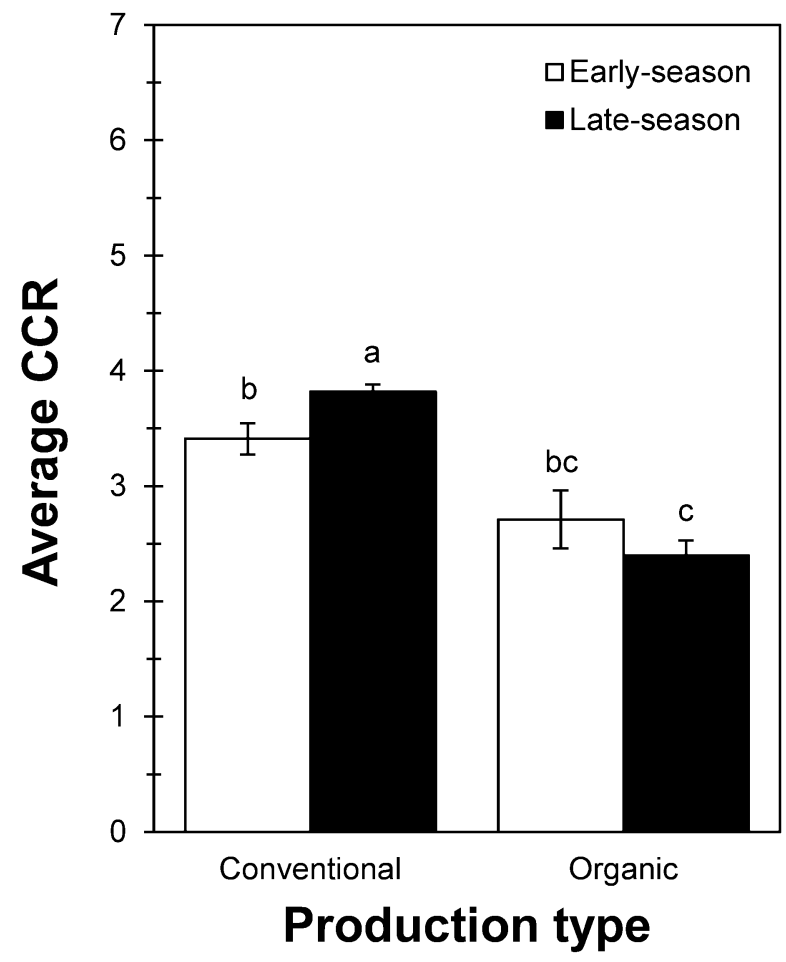

Fig. 4. Average number of chemical class resistances (CCR) of Botrytis cinerea isolates collected early- and late-season from conventional $(n=405)$ and organic $(n=103)$ California strawberry fields. Error bars are standard error of the means. Bars with different letters are significantly different according to a post-hoc Tukey's honest significant difference test $(\alpha=0.05)$. 


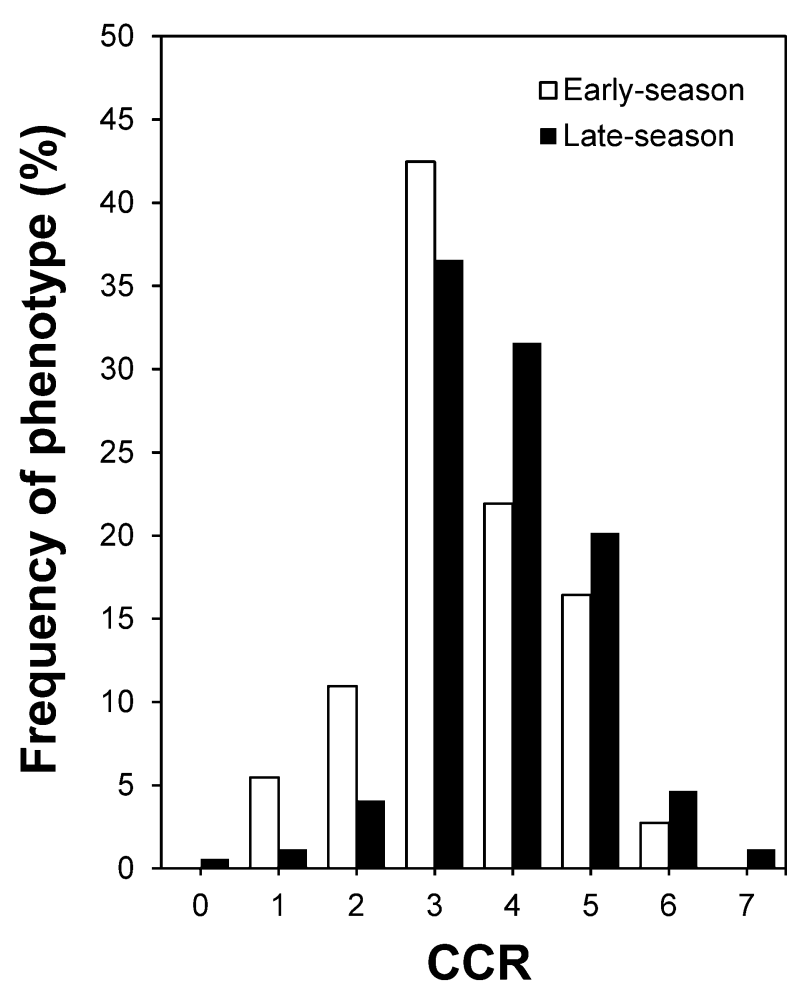

Fig. 5. Early-season $(n=71)$ and late-season $(n=334)$ frequencies of chemical class resistance (CCR) phenotypes from Botrytis cinerea isolates collected in conventional fields of the Southern, Central, and Northern strawberry growing districts of California.

Molecular basis of resistance and isolate identification. To determine the range of target gene variations in California isolates, a total of 40 isolates from the Southern, Central, and Northern districts were subjected to genetic analysis. They were determined as resistant or sensitive to multiple fungicides in the mycelial growth assay. Several known resistance-conferring mutations were found within each target gene: F196C, F412I, and F412S within erg27; I356N, I365N, and I365S within bos 1; E198A within the beta-tubulin gene; G143A within the cytb gene; $\mathrm{R} 351 \mathrm{C}$ and the $\Delta \mathrm{L} 497$ deletion within mrr1; and $\mathrm{H} 272 \mathrm{R}, \mathrm{H} 272 \mathrm{Y}$, $\mathrm{N} 230 \mathrm{I}$, and P225F within the $s d h B$ gene. The $\Delta \mathrm{L} 497$ deletion within the $m r r 1$ gene is only found in Botrytis group S genotypes and is referred to as MDR1h 
(Leroch et al. 2013). P225F was the only mutation associated with resistance to isofetamid. Isolates with this mutation were also cross-resistant to penthiopyrad, fluopyram, and boscalid. One isolate sensitive to pyraclostrobin contained a previously reported type I intron after codon 143 of the cytb gene (Leroux et al. 2010).

The fungicide resistance phenotype determined in the mycelial growth assay matched largely (61/65 matches; $93.8 \%$ accuracy) with the absence or presence of target gene mutations. Exceptions include two isolates (660 and $118 \mathrm{~A})$ that were sensitive to pyraclostrobin but revealed the G143A mutation; retesting confirmed both were resistant to pyraclostrobin. Another two isolates (44 and 746) were sensitive to boscalid but had the H272R mutation; retesting confirmed they both were resistant to boscalid.

Fungicide use survey. From our survey, we observed that fungicide applications were made throughout the harvest season. Harvest began and ended at different times for the three regions, but the average time between the first and last fungicide application was approximately six months. There was an average of 15 fungicide applications at an average interval of 12 days. The growing district did not significantly affect the frequency of fungicide use $(F[2,742]=1.583, p$-value $=0.206)$. The resistance management recommendation of rotating modes of action was universally employed. Captan, a multi-site fungicide, was the most frequently applied fungicide, while thiram (also multi-site) was rarely used (Fig. 6). The cyprodinil+fludioxonil premix, 
boscalid+pyraclostrobin premix, and fenhexamid were the most frequently applied site-specific products in the 32 surveyed fields.

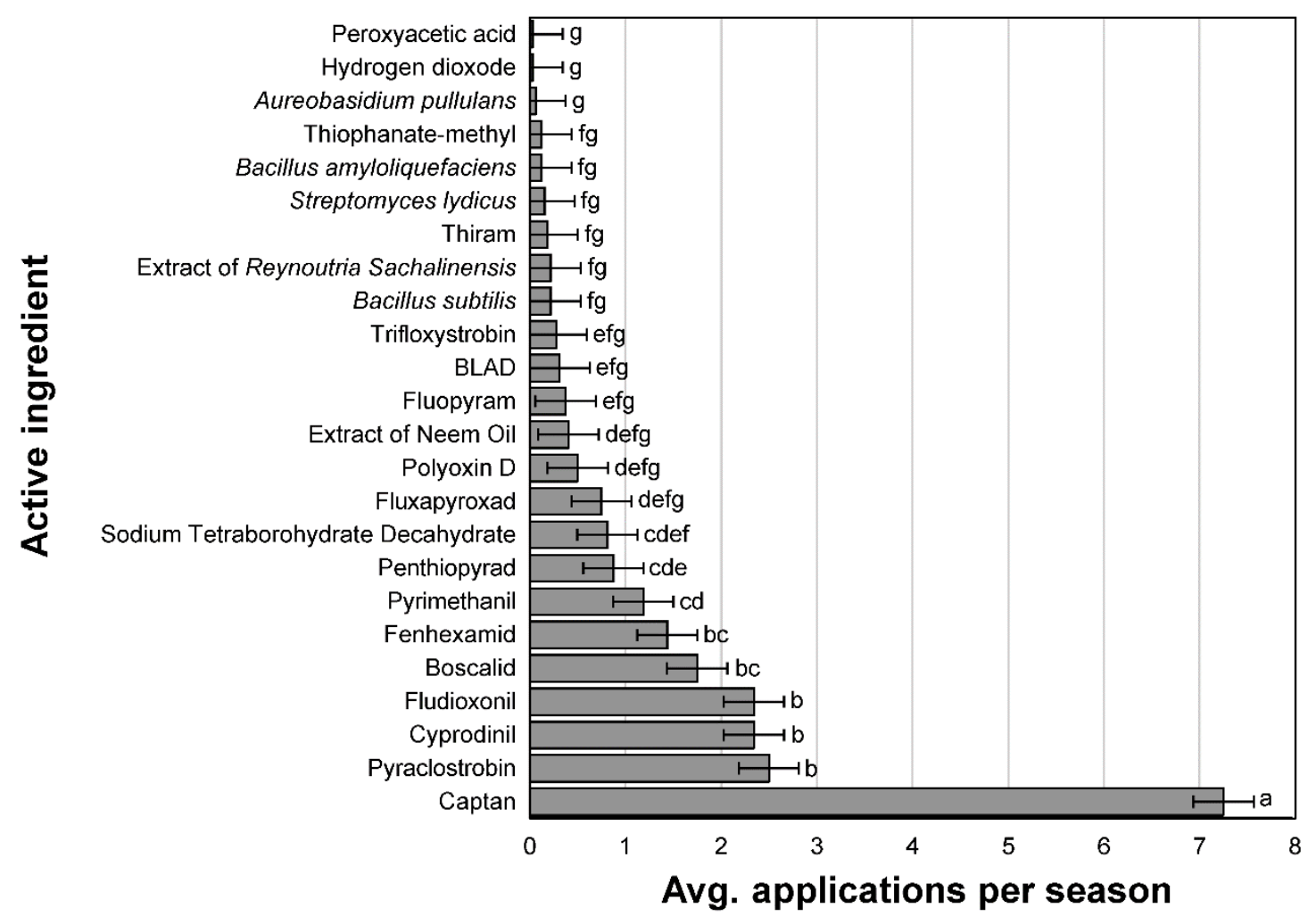

Fig. 6. Average number of applications per season of active ingredients labeled for gray mold of strawberry in 32 California conventional strawberry fields in 2016. Error bars are standard error of the means. Bars with different letters are significantly different according to a post-hoc Tukey's honest significant difference test $(\alpha=0.05)$.

\section{Discussion}

Resistance of $B$. cinerea to fungicides has been previously described in California (Adaskaveg and Gubler 2006; Mercier et al. 2010; Pokorny et al. 2016). This study builds on previous work by looking at a much larger number of isolates and fungicides across the major California strawberry fruit production 
districts and addresses the question of within-season shifts in fungicide sensitivity. Our results document resistance to all major site-specific chemical classes in isolates from all major fruit growing regions of the state and establish that resistant populations are widespread in California strawberry production. High frequencies of resistance to fenhexamid, pyraclostrobin, and thiophanatemethyl were found in most fields. Our survey showed that although the use of MBCs in fruit production fields was rare in 2016, resistance was high. This is likely a result of the use of benomyl and later thiophanate-methyl during the 1970s, 1980s and 1990s (Johnson et al. 1994; Young 2015). The common, MBC resistance-associated, E198A mutation may not entail a significant fitness cost, and other studies have also observed high frequencies of resistance (FernándezOrtuño et al. 2014; Johnson et al. 1994; Raposo et al. 1996). Because of very high levels of resistance to thiophanate-methyl (85\%), this product should not be used for gray mold management, but may still be effective against other diseases. Alternatively, pyraclostrobin and fenhexamid were used frequently within the 2016 season; their current popularity may be responsible for the high levels of resistance observed. The common G143A mutation that confers resistance to Qol fungicides was not found to accompany a loss in fitness in $B$. cinerea (Veloukas et al. 2014) and thus it is expected that the CA population will maintain high frequency of resistance even if FRAC 11 usage is curtailed. In contrast, a fitness cost related to fenhexamid resistance has been observed; therefore, reducing or eliminating its use for a period may yield a restoration of its efficacy (Adaskaveg and Gubler 2006; Billard et al. 2012). 
We observed a within-season shift in fungicide resistance profiles, which was likely induced by the regular application of fungicides and the associated selection pressure. While most applications were captan, a product that is not believed to select for resistance, site-specific fungicides were applied about half of the time. The frequency of resistance either increased or stayed the same for most fungicides. We observed a considerable increase in resistance frequency to cyprodinil, boscalid, and fenhexamid likely due to selection pressure (Adaskaveg and Gubler 2006), but not to fludioxonil. The scarcity of fludioxonil resistance supports the evidence that fludioxonil resistance is unstable within a population (Chen et al. 2016; Fernández-Ortuño et al. 2014). Resistance frequencies to thiophanate-methyl increased despite being rarely applied in the 2016 season. Along with the lack of fitness penalty of the E198A mutation in the beta-tubulin gene, the increasing shift in frequency of resistance may also be attributed to selection by association, a phenomenon suggesting that selection for resistance to a particular fungicide in populations with multifungicide resistant isolates can occur without direct selection pressure (Hu et al. 2016a). Resistance to iprodione may have decreased from the early-season to the late-season because this fungicide is primarily used in nurseries, and resistance to this active ingredient may entail a fitness cost (Johnson et al. 1994; Raposo et al. 1996).

There was a general shift towards isolates with increased CCR. Studies have shown CCR to fungicides changing from year to year (Fernández-Ortuño et al. 2014). The results of this study show a rapid, within-season shift in resistance to fungicides indicating that fungicides may lose efficacy during the course of the 
production season. The Southern district had the most drastic changes from early- to late-season, with resistance to boscalid, cyprodinil, and penthiopyrad increasing by over $40 \%$. The Southern district's production occurs during the rainy season, which may bring higher disease pressure leading to a more rapid resistance development. More research needs to be conducted to determine how different fungicides and fungicide programs affect frequencies of resistance over time within a field.

Isolates of $B$. cinerea varied in frequency of resistance to the four SDHI fungicides tested in this study. Specific mutations within the $s d h B$ region are associated with different resistance patterns among the SDHI fungicides (Hu et al. 2016b; Leroux et al. 2010). Mutations within $s d h B$ conferred the same resistance patterns as shown previously except that this study includes isofetamid (Fernández-Ortuño et al. 2017). The P225F mutation that conferred resistance to boscalid, fluopyram, isofetamid, and penthiopyrad has also been associated with resistance to fluxapyroxad (Hu et al. 2016b). Boscalid and penthiopyrad are among the longest-used SDHI's and tended to have higher frequencies of resistance. SDHI active ingredients are sold under six different trade names currently labeled for gray mold of strawberry. For this reason, care must be taken to not make successive applications of the same chemical class.

None of the fungicides tested in this study are labeled for use in organic strawberry production, yet a similar resistance profile was observed in earlyseason organic fields to that of early-season conventional fields. Resistant subpopulations of $B$. cinerea can be introduced into strawberry fields from wind- 
dispersed spores from nearby host plants (Fitt et al. 1985) or by colonized strawberry transplants (Oliveira et al. 2017). Strawberry nurseries typically do not apply fungicides for gray mold management, however similar chemical classes are applied for other diseases and non-target selection for resistant subpopulations of $B$. cinerea is possible. Resistance management cooperation between nurserymen and fruit growers is important so that selection pressure exerted in nurseries does not translate to loss of fungicide efficacy in fruit production fields.

Resistance management strategies are key for sustained site-specific fungicide efficacy. Isolates of $B$. cinerea with reduced sensitivity to the newest mode of action for gray mold of strawberry, FRAC 19, have already been found (Dowling et al. 2016). Therefore, multi-site fungicides should be the primary defense against gray mold, leaving highly effective, site-specific fungicides for times of high disease pressure (Hu et al. 2016a). Applying fungicides according to environmental conditions can be equally effective to a calendar-based spray program and can greatly reduce the number of applications per season (Bulger et al. 1987; Pavan et al. 2011). Cultural methods can also be effective ways to decrease gray mold pressure, thereby reducing the need to apply fungicides (Janisiewicz et al. 2016; Legard et al. 2000; Xiao et al. 2001). With industry-wide cooperation and careful use of site-specific fungicides, selection pressure can be reduced and the effective life of fungicides for gray mold control can be extended. 


\section{CHAPTER 3}

\section{First Report of Botrytis mali Causing Gray Mold on Strawberry in California}

As published: Cosseboom, S. D., Ivors, K. L., Schnabel, G., and Holmes, G. J. 2018. First report of Botrytis mali causing gray mold on strawberry in California. Plant Dis. 102:679.

S. D. Cosseboom, and K. L. Ivors, Department of Horticulture and Crop Science, California Polytechnic State University, San Luis Obispo, CA 93407;

G. Schnabel, Department of Plant and Environmental Sciences, Clemson University, Clemson, SC 29634; and G. J. Holmes, Strawberry Center, California Polytechnic State University, San Luis Obispo, CA 93407.

Gray mold of strawberry is caused by Botryotinia ricini, Botrytis caroliniana, Botrytis cinerea, Botrytis fragariae, and Botrytis mali, but only $B$. cinerea has been reported in California (Amiri et al. 2016; Dowling et al. 2017). In 2016, spores of Botrytis spp. were collected from strawberry fruit symptomatic of gray mold from 40 fields distributed throughout California's strawberry production acreage. A PCR-based assay of variability within the NEP2 gene was used to differentiate a proportion of these isolates between $B$. cinerea, $B$. fragariae, and B. mali (Dowling et al. 2017). Out of 80 isolates, one isolate collected from Coachella Valley was $B$. mali. In vitro colony morphology was slightly different from B. cinerea with more pronounced aerial mycelium (Fig. 7). Conidia 
measured 10.5 to $13.5 \times 8.7$ to $10.2 \mu \mathrm{m}$ (average $10.5 \times 8.8 \mu \mathrm{m}$ ). This isolate was also characterized as resistant to fludioxonil, reduced sensitivity to polyoxin D, and sensitive to boscalid, cyprodinil, fenhexamid, iprodione, isofetamid, penthiopyrad, pyraclostrobin, and thiophanate-methyl. The strawberry planting containing B. mali had history of applications of fludioxonil but not polyoxin D. The glyceraldehyde-3-phosphate-dehydrogenase (G3PDH) and beta-tubulin genes of this isolate were sequenced (O'Gorman et al. 2008) and deposited in GenBank with accession numbers MF975546 and MF975545, respectively. Search of sequences in GenBank revealed 100\% similarity for both regions with B. mali discovered in the Eastern United States (Dowling and Schnabel 2017). Koch's postulates were performed with this isolate and an isolate of $B$. cinerea by stab-inoculating 6 mature 'Monterey' strawberry fruit with a 21G needle to a depth of $1 \mathrm{~cm}$ and applying $30 \mu \mathrm{l}$ of a conidial suspension $\left(1 \times 10^{6} \mathrm{conidia} / \mathrm{ml}\right)$ to the wound. The same number of fruit were stabbed and received $30 \mu$ sterile deionized water as a control. After incubation at high humidity and at room temperature for 6 days post-inoculation, typical gray mold symptoms developed on both the $B$. cinerea and $B$. mali inoculated fruit. The pathogens recovered were morphologically identified as $B$. cinerea and $B$. mali, respectively. No fungal growth occurred on control fruit. B. mali has been previously described on strawberry in the Eastern United States (Dowling and Schnabel 2017), but not in California. This additional insight of the distribution of $B$. mali advances knowledge of this recently revived species. 


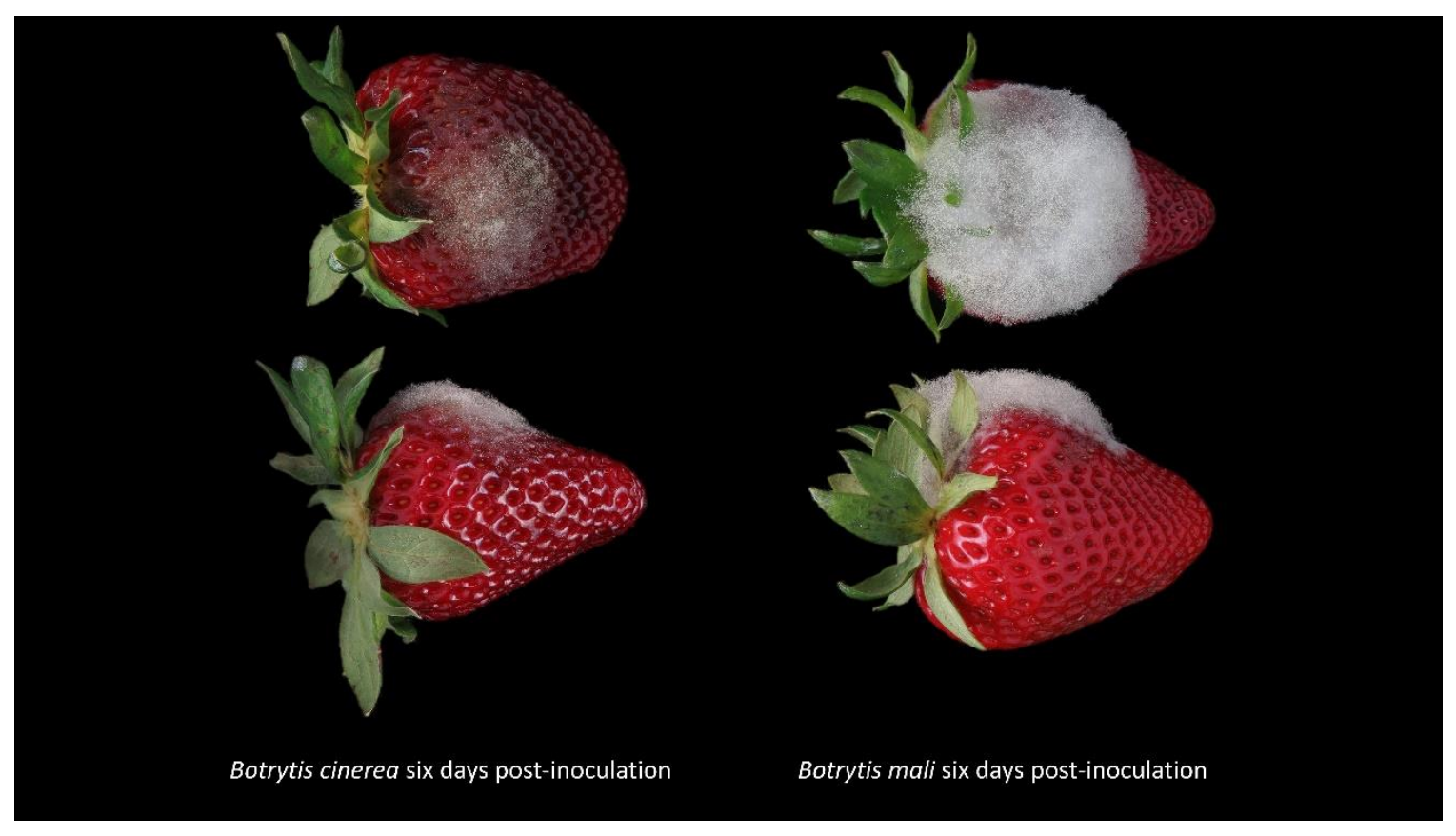

Fig. 7. Incubated strawberry fruit (cultivar Monterey) six days post-inoculation with Botrytis cinerea and Botrytis mali. Top row: top view. Bottom row: side view. 


\section{CHAPTER 4}

\section{Development of Resistance in Field Populations of Botrytis cinerea Following Exposure to Various Fungicide Programs}

\section{Introduction}

Modern site-specific fungicides have been used to manage diseases caused by Botrytis cinerea, including strawberry gray mold, since the late 1960s (Leroux et al. 2002). Multiple applications of fungicides are made per season to prevent strawberry gray mold because $B$. cinerea can infect and rot fruit throughout the 5 to 6 -month harvest season (Chapter 2). Many of the most effective fungicides are synthetic organic compounds that have a site-specific mode of action, which inhibits the function of a critical protein within a fungal pathogen (Ma and Michailides 2005). These chemicals are very effective at low concentrations and are often nontoxic to mammals. However, resistance has been reported to every effective chemical class (Fernández-Ortuño et al. 2014). Resistance to a site-specific fungicide typically arises from an advantageous, single point mutation in the gene that codes for the target protein of that fungicide (Ma and Michailides 2005). Multisite fungicides have not shown signs of resistance development despite their extensive use since their introduction decades ago. They are usually not as effective as site-specific fungicides in regards to $B$. cinerea (FRAC 2017). Multisite fungicides are often used in rotation or in mixture (tank-mixed) with site-specific fungicides to prevent gray mold while decreasing selection pressure for resistance to the site-specific fungicides 
(Northover et al. 1986). Two multisite fungicides, captan and thiram, are labeled for gray mold of strawberry. The site-specific fungicides labeled for gray mold have been placed into eight chemical classes according to their cross-resistance behavior: anilinopyrimidines (APs), dicarboximides (DCs), hydroxyanilides (HAs), methyl benzimidazole carbamates (MBCs), phenylpyrroles (PPs), polyoxins, quinone outside inhibitors (Qols), and succinate dehydrogenase inhibitors (SDHIs) (FRAC 2017).

A multitude of theoretical models gives evidence that applying a high resistance-risk (site-specific) fungicide consecutively will select for more resistance to that chemical class than applying that high-risk fungicide with a lowrisk (multisite) fungicide in a mixture or rotation (van den Bosch et al. 2014). Yet, a study of solo, rotation, and tank-mixing spray programs in strawberries showed that a tank-mix or rotation of a DC and multisite fungicide did not result in less resistance than a DC alone. Furthermore, resistance to MBCs and DCs was correlated with the number of applications of those chemical classes (Hunter et al. 1987; Johnson et al. 1994; Northover et al. 1986). In vitro fitness cost studies can conflict on whether resistance to a chemical class like SDHI is associated with reduced fitness (Karaoglanidis et al. 2010; Lalève et al. 2014; Veloukas et al. 2014; Yin et al. 2011). Resistance to fungicides such as DCs, HAs, PPs, and polyoxins has been associated with measurable fitness costs, while resistance to APs, MBCs and Qols has not (Bardas et al. 2008; Billard et al. 2012; Dowling et al. 2016; Raposo et al. 2000; Ren et al. 2016; Yourman et al. 2001). In vivo studies provide practical evidence of the effects of a resistance-associated 
fitness cost on a population. In the absence of exposure, DC resistant field populations of $B$. cinerea have declined in frequency of resistance (Hunter et al. 1987; Johnson et al. 1994; Katan 1982). The objective of this study was to monitor frequencies of fungicide resistance in populations of $B$. cinerea before, during, and after sequential rotation, tank-mix + rotation, or solo fungicide treatments. Active ingredients in the top four most frequently applied fungicides labeled for gray mold of strawberry in California were tested: boscalid (SDHI) captan (multisite), fenhexamid (HA), and fludioxonil (PP) (Cosseboom et al. 2017).

\section{Materials and Methods}

Field trial design. The field trial was conducted in Field 25, block 3 at California Polytechnic State University in San Luis Obispo, California. The trial consisted of nine plastic-mulch covered, raised beds that were $122 \mathrm{~cm}$ wide, 46 $\mathrm{m}$ long, $30 \mathrm{~cm}$ high, and $163 \mathrm{~cm}$ between bed centers. Every other bed was planted with cereal rye (Secale cereale L.) cv. Merced. The four beds interspersed between the cereal rye planted beds contained eight plots of 30 strawberry plants cv. San Andreas $(284 \mathrm{~cm})$, a $41 \mathrm{~cm}$ buffer, and a $183 \mathrm{~cm}$ barrier planting of cereal rye, thus surrounding each strawberry plot with cereal rye on all four sides. Strawberries were transplanted on 21 November 2016 and cereal rye was planted 1 December 2016. The cereal rye was used to prevent inter-plot interference from wind-dispersed conidia. A single Netafim SuperNet micro sprinkler emitter (Netafim USA, Fresno, CA) was placed in the center of each plot of 30 strawberry plants. Immediately following planting, the strawberry 
plants were overhead irrigated via micro sprinklers for one month to facilitate plant establishment.

Treatments were arranged in a randomized complete block design with four blocks and seven treatments replicated once in each block. Fungicides used for the field trial were boscalid + pyraclostrobin (Pristine; BASF Corporation, Ludwigshafen, Germany), captan (Captan 80WDG; Arysta LifeScience, Cary, NC), cyprodinil + fludioxonil (Switch 62.5WG; Syngenta Crop Protection, Basel, Switzerland), and fenhexamid (Elevate 50WDG; Arysta LifeScience, Cary, NC). The experiment included a non-treated control, and six other treatments applied for six consecutive weeks (Table 3). Each treatment was applied with a $\mathrm{CO}_{2}$ pressurized backpack spray system and handheld boom.

Isolate collection and laboratory assay. Depending on the weather, micro sprinklers were employed intermittently throughout the experiment to promote disease development in strawberry flowers and fruit. Isolates of $B$. cinerea were collected at five times throughout this experiment. At each collection time, four isolates were collected per strawberry plot yielding 112 isolates per collection date. Isolates were collected in 21-day intervals starting at one day before the first fungicide application. Isolates were collected by brushing a sterile, individually wrapped cotton swab against a sporulating lesion of gray mold. If not enough sporulating fruit could be found in the field, green fruit were collected, frozen overnight, and surface sterilized for one minute in $1 \%$ sodium hypochlorite. These fruit were then incubated at room temperature in humidity chambers until sporulation occurred. 
Isolates were tested for resistance to boscalid, fenhexamid, and fludioxonil using a visually assessed mycelial growth assay. Each isolate was transferred with a sterile toothpick from the swab to four wells ( $15 \mathrm{~mm}$ diameter) of 24-well plates (Thermo Fisher Scientific, Waltham, MA). The four wells contained different discriminatory dosage treatments mixed with growing media: nonamended malt extract agar (MEA), $75 \mu \mathrm{g} / \mathrm{ml}$ boscalid in yeast bacto acetate agar (YBA), $50 \mu \mathrm{g} / \mathrm{ml}$ fenhexamid in MEA, and $0.5 \mu \mathrm{g} / \mathrm{ml}$ fludioxonil in MEA. Formulated products containing only boscalid (Endura; BASF Corporation, Ludwigshafen, Germany), fenhexamid (Elevate 50WDG; Arysta LifeScience, Cary, NC), and fludioxonil (Scholar SC; Syngenta Crop Protection, Basel, Switzerland) were used. Inoculated 24 -well plates were incubated at $22^{\circ} \mathrm{C}$ for 4 days and diametric colony growth was visually assessed in each well as: sensitive (S) for less than $20 \%$ diametric growth, and resistant $(R)$ for more than $20 \%$ diametric growth with respect to the well diameter. A Bonferroni adjusted, one-tailed, Fisher's exact test was used to compare the frequency of resistance observed between collection I and collection III and between collection III and collection $V$ for each treatment. A repeat experiment will be conducted in 201718. 
Table 3. Field trial fungicide treatments evaluated for resistance response in Botrytis cinerea

\begin{tabular}{llll}
\hline Treatment name & Trade name & Treatment sequence & Rate \\
\hline Non-treated & & n/a & n/a \\
Boscalid + pyraclostrobin (P) & Pristine & P, P, P, P, P, P & $23 \mathrm{fl} \mathrm{oz} /$ acre \\
Cyprodinil + fludioxonil (S) & Switch 62.5WG & S, S, S, S, S, S & $14 \mathrm{fl} \mathrm{oz/acre}$ \\
Fenhexamid (E) & Elevate 50WDG & E, E, E, E, E, E & $1.5 \mathrm{lb} /$ acre \\
Captan (C) & Captan 80 WDG & C, C, C, C, C, C & $3.75 \mathrm{lb} / \mathrm{acre}$ \\
Rotation & & P, S, E, P, S, E & P, S, E \\
Tank-mix + rotation & & P + C, S + C, E + C, P & C + low (P, S, \\
& & + C, S + C, E + C & E) \\
\hline
\end{tabular}

a The tank-mix + rotation used low rates of $\mathrm{P}(18.5 \mathrm{fl}$ oz/acre $), \mathrm{S}$ (11 fl oz/acre), and $\mathrm{E}(1 \mathrm{lb} / \mathrm{acre})$.

\section{Results}

Of isolates collected prior to fungicide applications (collection I), 7, 21, and $3 \%$ of isolates were resistant to boscalid, fenhexamid, and fludioxonil, respectively. Collection I frequencies of resistance were relatively similar among treatments. Resistance to boscalid and fludioxonil remained relatively steady throughout the trial, while resistance to fenhexamid was more volatile (Fig. 8). In plots treated with fenhexamid, resistance to fenhexamid increased 6 days after the third application (collection II), and again until 6 days after the last application (collection III). At 27 (collection IV) and 48 days (collection V) after the last application of fenhexamid, resistance to fenhexamid decreased. Frequency of resistance significantly increased from collection I to collection III in the fenhexamid, tank-mix, and tank-mix + rotation treatments. Frequency of resistance significantly decreased from collection III to collection V in the rotation treatment only. Fenhexamid resistance remained relatively constant in the nontreated plots throughout the trial; however, fenhexamid resistance did erratically change in plots treated with fungicides besides fenhexamid. 

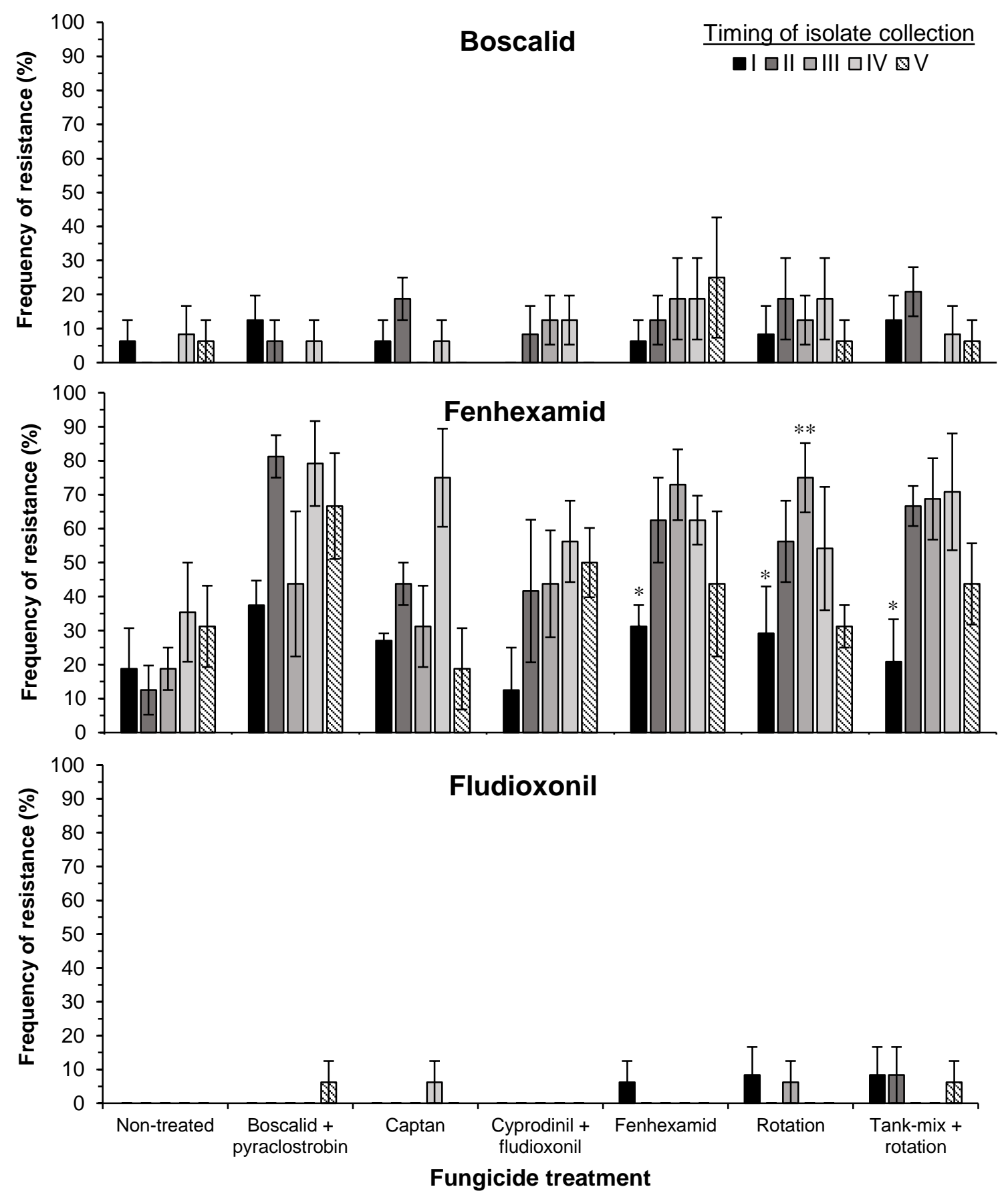

Fig. 8. Frequencies of resistance of Botrytis cinerea to boscalid (top), fenhexamid (middle), and fludioxonil (bottom) observed in plots of strawberries treated with repeated applications of fungicides at five collection points in the trial. Collections timings: (I) one day before first fungicide application, (II) six days after third fungicide application, (III) six days after sixth fungicide application, (IV) 27 days after sixth fungicide application, and (V) 48 days after sixth fungicide application. Statistical significance of frequency of resistance between I and III is represented by an asterisk $\left(^{*}\right)$, and III and V by a double asterisk $\left(^{* *}\right)(p<0.05)$. 


\section{Discussion}

The $B$. cinerea population in field 25 contained fungicide resistant phenotypes that were initially rarely resistant to boscalid (7\%) and fludioxonil (3\%), but were commonly resistant to fenhexamid (21\%). This is similar to our resistance survey in chapter 2 and surveys in the Eastern United States and Spain; however, boscalid resistance was less frequent in our field (FernándezOrtuño et al. 2016). This could be because resistance is variable among fields (Fernández-Ortuño et al. 2014). Despite repeated applications of boscalid and fludioxonil, resistance to these fungicides did not to increase or change regardless of the fungicide treatment or rotation program. The initial level of resistance to both of these fungicides may have been too low to observe a meaningful shift in resistance in 12 weeks. Although micro-sprinklers were utilized to create longer wetness periods and thereby increase gray mold incidence, gray mold incidence was often so low that fruit needed to be incubated for gray mold to develop. A population in a field with greater disease pressure may have been more prone to selection pressure.

The populations of $B$. cinerea within the plots treated with fenhexamid displayed a response in frequency of resistance, tending to increase with selection pressure, and tending to decrease without it. The high level of resistance to fenhexamid in the first collection may have made the population shift more rapidly towards resistance. The fungicide rotation or tank-mix + rotation treatments did not appear to delay the selection for resistance to fenhexamid. By collection III, the fenhexamid treatment plots were exposed to six 
applications of fenhexamid, while the rotation and tank-mix + rotation treatment plots were only exposed to two applications of fenhexamid. Other studies have also observed that tank-mixing a multisite fungicide with a site-specific fungicide may not sufficiently delay resistance development to the site-specific fungicide (Hunter et al. 1987; Northover et al. 1986). This may be due to the number of applications per season in a crop like strawberries (van den Bosch et al. 2014) and the limited efficacy of multisite fungicides like captan and thiram (Adaskaveg et al. 2017).

Inter-plot interference is a common issue in similar fungicide resistance studies (Northover and Matteoni, 1986). The planting of cereal rye appeared to prevent this phenomenon because the frequency of resistance to fenhexamid in the non-treated plots stayed relatively constant throughout the trial. However, resistance to fenhexamid was variable in other treatment plots that were not exposed to fenhexamid. Even though this variability was not observed in the nontreated plots, this may still be attributable to inter-plot interference. The thick stand of cereal rye appeared to block wind from blowing spores between plots horizontally, but the plots were exposed to spores dropping into plots from above. Selection by association, also known as genetic hitchhiking, could also contribute to this shift (Hu et al. 2016a). The application of a fungicide such as boscalid may have selected for isolates that are dual resistant to boscalid and fenhexamid. The replication of this trial will help illuminate if this is truly the case. Analyzing the phenotypes of single-spore isolates collected in these plots throughout the trial would also help characterize this as selection by association. 
The decrease in resistance in the absence of selection pressure exhibits the effects of the fitness cost associated with fenhexamid resistance (Billard et al. 2012; Saito et al. 2014). In a field with a high level of fungicide resistance (with a resistance-associated fitness cost), reducing or eliminating its use for a period of time may yield a restoration of its efficacy. Yet, this study shows that a population may become effectively resistant after exposure to only one or two applications of a high-risk chemical class. Therefore, DC and HA use should be limited. Alternatively, fungicides with persistent resistance issues (e.g., Qols and MBCs) should not be considered for gray mold management for the foreseeable future. 


\section{REFERENCES}

Agrios, G. N. 2005. Plant Pathology 5th ed. Academic Press, New York, NY.

Abro, M. A., Lecompte, F., Bryone, F., and Nicot, P. C. 2013. Nitrogen fertilization of the host plant influences production and pathogenicity of Botrytis cinerea secondary inoculum. Phytopathology 103:261-7.

Adaskaveg, J. E. and Gubler, W. D. 2006. Management of pre- and postharvest gray mold of strawberry. Pages 47-59 in: California Strawberry Commission Annual Production Research Report 2005-2006. California Strawberry Commission. Watsonville, CA.

Adaskaveg, J. E., Gubler, D., and Michailides, T. J. 2017. Fungicides, bactericides, and biologicals for deciduous tree fruit, nut, strawberry, and vine crops. Online publication. University of California Division of Agriculture and Natural Resources. http://ipm.ucanr.edu/PDF/PMG/fungicideefficacytiming.pdf

Amiri, A., Heath, S. M., and Peres, N. A. 2013. Phenotypic characterization of multifungicide resistance in Botrytis cinerea isolates from strawberry fields in Florida. Plant Dis. 97:393-401.

Amiri, A., Heath, S. M., and Peres, N. A. 2014. Resistance to fluopyram, fluxapyroxad, and penthiopyrad in Botrytis cinerea from strawberry. Plant Dis. 98:532-539.

Amiri, A., Onofre, R. B., and Peres, N. A. 2016. First report of gray mold caused by Botryotinia ricini (Amphobotrys ricini) on strawberry in the United States. Plant Dis. 100:1007.

Bardas, G. A., Myresiotis, C. K., and Karaoglanidis, G. S. 2008. Stability and fitness of anilinopyrimidine-resistant strains of Botrytis cinerea. Phytopathology 98:443450.

Bartlett, D. W., Clough, J. M., Godwin, J. R., Hall, A. A., Hamer, M., and ParrDobrzanski, B. 2002. The strobilurin fungicides. Pest Manag. Sci. 58:649-662.

Billard, A., Fillinger, S., Leroux, P., Lachaise, H., Beffa, R., and Debieu, D. 2012. Strong resistance to the fungicide fenhexamid entails a fitness cost in Botrytis cinerea, as shown by comparisons of isogenic strains. Pest Manag. Sci. 68:684-691.

Boff, P., Kohl, J., Jansen, M., Horsten, P. J. F. M., Lombaers-van der Plas, C., and Gerlagh, M. 2002. Biological control of gray mold with Ulocladium atrum in annual strawberry crops. Plant Dis. 86:220-224.

Bollen, G. J., and Scholten, G. 1971. Acquired resistance to benomyl and some other systemic fungicides in a strain of Botrytis cinerea in cyclamen. Netherlands $\mathrm{J}$. Plant Pathol. 77:83-90.

Braun, P. G., and Sutton, J. C. 1987. Inoculum sources of Botrytis cinerea in fruit rot of strawberries in Ontario. Can. J. Plant Pathol. 9:1-5.

Bristow, P. R., McNicol, R. J., and Williamson, B. 1986. Infection of strawberry flowers by Botrytis cinerea and its relevance to grey mould development. Ann. Appl. Biol. 109:545-554. 
Bulger, M. A., Ellis, M. A., and Madden, L. V. 1987. Influence of temperature and wetness duration on infection of strawberry flowers by Botrytis cinerea and disease incidence of fruit originating from infected flowers. Phytopathology 77:1225-1230.

Burlakoti, R., Zandstra, J., and Jackson, K. Comparison of epidemiology of gray mold, anthracnose fruit rot, and powdery mildew in day-neutral strawberries in field and high-tunnel conditions in Ontario. Int. J. Fr. Sci. 13:19-27.

Chaube, H. S., and Pundhir, V. S. 2005. Crop diseases and their management. PHI Learning, New Delhi, India.

Chen, S. N., Luo, C. X., Hu, M. J., and Schnabel, G. 2016. Fitness and competitive ability of Botrytis cinerea isolates with resistance to multiple chemical classes of fungicides. Phytopathology 106:997-1005.

Cheng, C.-H., Yang, C.-A., and Peng, K.-C. 2012. Antagonism of Trichoderma harzianum ETS 323 on Botrytis cinerea mycelium in culture conditions. Phytopathology 102:1054-1063.

Chi, M.-H., Park, S.-Y., and Lee, Y.-H. 2009. A quick and safe method for fungal DNA extraction. Plant Pathol. J. 25:108-111.

Cosseboom, S. D., Ivors, K. L., and Holmes, G. J. 2017. Grower fungicide use patterns for control of gray mold and powdery mildew of strawberry in California. (Abstr.) Phytopathology 107:S5.184.

Cosseboom, S. D., Ivors, K. L., Schnabel, G., Holmes, G. J. 2018. First report of Botrytis mali causing gray mold on strawberry in California. Plant Dis. 102:679.

CSC. 2017. California strawberry acreage survey - update. Online publication. California Strawberry Commission. http://www.calstrawberry.com/Portals/0/Reports/Industry Reports/Acreage Survey/2017 California Strawberry Acreage Survey - Update.pdf?ver=2017-0803-21110

Cui, W., Beever, R. E., Parkes, S. L., and Templeton, M. D. 2004. Evolution of an osmosensing histidine kinase in field strains of Botryotinia fuckeliana (Botrytis cinerea) in response to dicarboximide fungicide usage. Phytopathology 94:1129_ 35.

Darrow, G. 1966. The strawberry. Holt, Rinehart and Winston, Boston, MA.

Debieu, D., Bach, J., Hugon, M., Malosse, C., and Leroux, P. 2001. The hydroxyanilide fenhexamid, a new sterol biosynthesis inhibitor fungicide efficient against the plant pathogenic fungus Botryotinia fuckeliana (Botrytis cinerea). Pest Manag. Sci. 57:1060-1067.

Deising, H. B., Reimann, S., and Pascholati, S. F. 2008. Mechanisms and significance of fungicide resistance. Brazilian J. Microbiol. 39:286-295.

Delp, C. J. 1988. Fungicide resistance in North America. APS Press, St. Paul, MN. 
Dowling, M. E., Hu, M.-J., Schmitz, L. T., Wilson, J. R., and Schnabel, G. 2016. Characterization of Botrytis cinerea isolates from strawberry with reduced sensitivity to polyoxin D zinc salt. Plant Dis. 100:2057-2061.

Dowling, M. E., Hu, M.-J., and Schnabel, G. 2017. Identification and characterization of Botrytis fragariae isolates on strawberry in the United States. Plant Dis. 101:1769-1773.

Dowling, M. E., and Schnabel, G. 2017. First report of Botrytis mali causing gray mold on strawberry in the United States. Plant Dis. 101:1034.

Elad, Y., Williamson, B., Tudzynski, P., and Delen, N. 2004. Botrytis spp. and the diseases they cause in agricultural systems - an introduction. Pages 1-8 in: Botrytis: Biology, Pathology and Control, eds. Y. Elad, Brian Williamson, Paul Tudzynski, and N. Delen. Springer, Dordrecht, The Netherlands.

Endo, A., Kakiki, K., and Misato, T. 1970. Mechanism of action of the antifugal agent polyoxin D. J. Bacteriol. 104:189-196.

Fan, F., Hamada, M. S., Li, N., Li, G. Q., and Luo, C. X. 2017. Multiple fungicide resistance in Botrytis cinerea from greenhouse strawberries in Hubei Province, China. Plant Dis. 101:601-606.

Faretra, F., and Pollastro, S. 1993. Isolation, characterization and genetic analysis of laboratory mutants of Botryotinia fuckeliana resistant to the phenylpyrrole fungicide CGA 173506. Mycol. Res. 97:620-624.

Farrar, J. J., Baur, M. E., and Elliott, S. F. 2016. Measuring IPM impacts in California and Arizona. J. Integr. Pest Manag. 7:1-6

Fernández-Ortuño, D., Bryson, P. K., Grabke, A., and Schnabel, G. 2013. First report of fludioxonil resistance in Botrytis cinerea from a strawberry field in Virginia. Plant Dis. 97:848.

Fernández-Ortuño, D., Chen, F., and Schnabel, G. 2012. Resistance to pyraclostrobin and boscalid in Botrytis cinerea isolates from strawberry fields in the Carolinas. Plant Dis. 96:1198-1203.

Fernández-Ortuño, D., Grabke, A., Bryson, P. K., Amiri, A., Peres, N. A., and Schnabel, G. 2014. Fungicide resistance profiles in Botrytis cinerea from strawberry fields of seven southern U.S. states. Plant Dis. 98:825-833.

Fernández-Ortuño, D., Grabke, A., Li, X., and Schnabel, G. 2015. Independent emergence of resistance to seven chemical classes of fungicides in Botrytis cinerea. Phytopathology 105:424-432.

Fernández-Ortuño, D., Li, X., Wang, F., and Schnabel, G. 2012. First report of gray mold of strawberry caused by Botrytis caroliniana in North Carolina. Plant Dis. 96:914.

Fernández-Ortuño, D., Pérez-García, A., Chamorro, M., de la Peña, E., de Vicente, A., and Torés, J. A. 2017. Resistance to the SDHI fungicides boscalid, fluopyram, fluxapyroxad, and penthiopyrad in Botrytis cinerea from commercial strawberry fields in Spain. Plant Dis. 101:1306-1313. 
Fernández-Ortuño, D., Torés, J. A., Chamorro, M., Pérez-García, A., and de Vicente, A. 2016. Characterization of resistance to six chemical classes of site-specific fungicides registered for gray mold control on strawberry in Spain. Plant Dis. 100:2234-2239.

Fernández-Ortuño, D., Torés, J. A., De Vicente, A., and Pérez-García, A. 2008. Mechanisms of resistance to $Q$ ol fungicides in phytopathogenic fungi. Int. Microbiol. 11:1-9.

Fillinger, S., Leroux, P., Auclair, C., Barreau, C., Al Hajj, C., and Debieu, D. 2008. Genetic analysis of fenhexamid-resistant field isolates of the phytopathogenic fungus Botrytis cinerea. Antimicrob. Agents Chemother. 52:3933-3940.

Fitt, B. D. L., Creighton, N. F., and Bainbridge, A. 1985. Role of wind and rain in dispersal of Botrytis fabae conidia. Trans. Br. Mycol. Soc. 85:307-312.

FRAC. 2017. FRAC code list: fungicides sorted by mode of action. Online publication. Fungicide Resisance Action Committee. http://www.frac.info/docs/defaultsource/publications/frac-code-list/frac-code-list-2017-final.pdf?sfvrsn=2

Furukawa, K., Randhawa, A., Kaur, H., Mondal, A. K., and Hohmann, S. 2012. Fungal fludioxonil sensitivity is diminished by a constitutively active form of the group III histidine kinase. FEBS Lett. 586:2417-2422.

Grabke, A., Fernández-Ortuño, D., Amiri, A., Li, X., Peres, N. A., Smith, P., and Schnabel, G. 2014. Characterization of iprodione resistance in Botrytis cinerea from strawberry and blackberry. Phytopathology 104:396-402.

Grabke, A., Fernández-Ortuño, D., and Schnabel, G. 2013. Fenhexamid resistance in Botrytis cinerea from strawberry fields in the Carolinas is associated with four target gene mutations. Plant Dis. 97:271-276.

Grabke, A., and Stammler, G. 2015. A Botrytis cinerea population from a single strawberry field in Germany has a complex fungicide resistance pattern. Plant Dis. 99:1078-1086.

Hancock, J. F. 1999. Strawberries. CABI Publishing, Oxfordshire, United Kingdom.

Holz, G., Coertze, S., and Williamson, B. 2004. The ecology of Botrytis on plant surfaces. Pages 9-24 in Botrytis: Biology, Pathology and Control, eds. Y. Elad, Brian Williamson, Paul Tudzynski, and N. Delen. Springer, Dordrecht, The Netherlands.

Hu, M.-J., Dowling, M. E., and Schnabel, G. 2018. Genotypic and phenotypic variations in Botrytis spp. isolates from single strawberry flowers. Plant Dis. 102:179-184.

Hu, M.-J., Cox, K. D., and Schnabel, G. 2016a. Resistance to increasing chemical classes of fungicides by virtue of "selection by association" in Botrytis cinerea. Phytopathology 106:1513-1520.

Hu, M.-J., Fernández-Ortuño, D., and Schnabel, G. 2016b. Monitoring resistance to SDHI fungicides in Botrytis cinerea from strawberry fields. Plant Dis. 100:959965. 
Hunter, T., Brent, K. J., Carter, G. A., and Hutcheon, J. A. 1987. Effects of fungicide spray regimes on incidence of dicarboximide resistance in grey mould (Botrytis cinerea) on strawberry plants. Ann. Appl. Biol. 110:515-525.

Janisiewicz, W. J., Takeda, F., Glenn, D. M., Camp, M. J., and Jurick, W. M. 2016. Dark period following UV-C treatment enhances killing of Botrytis cinerea conidia and controls gray mold of strawberries. Phytopathology 106:386-394.

Jarvis, W. R. 1962. The dispersal of spores of Botrytis cinerea fr. in a raspberry plantation. Trans. Br. Mycol. Soc. 45:549-559.

Johnson, K. B., Sawyer, T. L., and Powelson, M. L. 1994. Frequency of benzimidazoleresistant and dicarboximide-resistant strains of Botrytis cinerea in western Oregon small fruit and snap bean plantings. Plant Dis. 78:572-577.

Kable, P. F., and Jeffery, H. 1980. Selection for tolerance in organisms exposed to sprays of biocide mixtures: a theoretical model. Phytopathology 70:8-12.

Karaoglanidis, G. S., Luo, Y., and Michailides, T. J. 2010. Competitive ability and fitness of Alternaria alternata isolates resistant to Qol fungicides. Plant Dis. 95:178-182.

Katan, T. 1982. Resistance to 3,5-dichlorophenyl-N-cyclic imide ("dicarboximide") fungicides in the grey mould pathogen Botrytis cinerea on protected crops. Plant Pathol. 31:133-141.

Köhl, J., Gerlagh, M., and Grit, G. 2000. Biocontrol of Botrytis cinerea by Ulocladium atrum in different production systems of cyclamen. Plant Dis. 84:569-573.

Köhl, J., and Molhoek, W. M. 2001. Effect of water potential on conidial germination and antagonism of Ulocladium atrum against Botrytis cinerea. Phytopathology 91:485-491.

Konstantinou, S., Veloukas, T., Leroch, M., Menexes, G., Hahn, M., and Karaoglanidis, G. 2015. Population structure, fungicide resistance profile, and sdhB mutation frequency of Botrytis cinerea from strawberry and greenhouse-grown tomato in Greece. Plant Dis. 99:240-248.

Kretschmer, M., Leroch, M., Mosbach, A., Walker, A. S., Fillinger, S., Mernke, D., Schoonbeek, H. J., Pradier, J. M., Leroux, P., and De Waard, M. A. 2009. Fungicide-driven evolution and molecular basis of multidrug resistance in field populations of the grey mould fungus Botrytis cinerea. PLoS Pathog. 5:e1000696.

Lalève, A., Fillinger, S., and Walker, A.-S. 2014. Fitness measurement reveals contrasting costs in homologous recombinant mutants of Botrytis cinerea resistant to succinate dehydrogenase inhibitors. Fungal Genet. Biol. 67:24-36.

Legard, D. E., Xiao, C. L., Mertely, J. C., and Chandler, C. K. 2000. Effects of plant spacing and cultivar on incidence of Botrytis fruit rot in annual strawberry. Plant Dis. 84:531-538.

Legard, D. E., Xiao, C. L., Mertely, J. C., and Chandler, C. K. 2001. Management of Botrytis fruit rot in annual winter strawberry using captan, thiram, and iprodione. Plant Dis. 85:31-39. 
Leroch, M., Plesken, C., Weber, R. W. S., Kauff, F., Scalliet, G., and Hahn, M. 2013. Gray mold populations in German strawberry fields are resistant to multiple fungicides and dominated by a novel clade closely related to Botrytis cinerea. Appl. Environ. Microbiol. 79:159-167.

Leroux, P., Chapeland, F., Desbrosses, D., and Gredt, M. 1999. Patterns of crossresistance to fungicides in Botryotinia fuckeliana (Botrytis cinerea) isolates from French vineyards. Crop Prot. 18:687-697.

Leroux, P., Fritz, R., Debieu, D., Albertini, C., Lanen, C., Bach, J., Gredt, M., and Chapeland, F. 2002. Mechanisms of resistance to fungicides in field strains of Botrytis cinerea. Pest Manag. Sci. 58:876-888.

Leroux, P., Gredt, M., Leroch, M., and Walker, A.-S. 2010. Exploring mechanisms of resistance to respiratory inhibitors in field strains of Botrytis cinerea, the causal agent of gray mold. Appl. Environ. Microbiol. 76:6615-6630.

$\mathrm{Li}, \mathrm{H}$., and Xiao, C. L. 2008. Characterization of fludioxonil-resistant and pyrimethanilresistant phenotypes of Penicillium expansum from apple. Phytopathology 98:427-435.

Li, X., Fernández-Ortuño, D., Chen, S., Grabke, A., Luo, C.-X., Bridges, W. C., Schnabel, G. 2014. Location-specific fungicide resistance profiles and evidence for stepwise accumulation of resistance in Botrytis cinerea. Plant Dis. 98:10661074.

Luck, J. E., and Gillings, M. R. 1995. Rapid identification of benomyl resistant strains of Botrytis cinerea using the polymerase chain reaction. Mycol. Res. 99:1483-1488.

Ma, Z., and Michailides, T. J. 2005. Advances in understanding molecular mechanisms of fungicide resistance and molecular detection of resistant genotypes in phytopathogenic fungi. Crop Prot. 24:853-863.

Ma, Z., Yan, L., Luo, Y., and Michailides, T. J. 2007. Sequence variation in the twocomponent histidine kinase gene of Botrytis cinerea associated with resistance to dicarboximide fungicides. Pestic. Biochem. Physiol. 88:300-306.

MacKenzie, S. J., and Peres, N. A. 2012. Use of leaf wetness and temperature to time fungicide applications to control Botrytis fruit rot of strawberry in Florida. Plant Dis. 96:529-536.

Mamiev, M., Korolev, N., and Elad, Y. 2013. Resistance to polyoxin AL and other fungicides in Botrytis cinerea collected from sweet basil crops in Israel. Eur. J. Plant Pathol. 137:79-91.

Mercier, J., Kong, M., and Cook, F. 2010. Fungicide resistance among Botrytis cinerea isolates from California strawberry fields. Plant Health Prog. doi:10.1094/PHP2010-0806-01-RS

Mertely, J. C., Chandler, C. K., Xiao, C. L., and Legard, D. E. 2000. Comparison of sanitation and fungicides for management of Botrytis fruit rot of strawberry. Plant Dis. 84:1197-1202. 
Mertely, J. C., MacKenzie, S. J., and Legard, D. E. 2002. Timing of fungicide applications for Botrytis cinerea based on development stage of strawberry flowers and fruit. Plant Dis. 86:1019-1024.

Myresiotis, C. K., Karaoglanidis, G. S., and Tzavella-Klonari, K. 2007. Resistance of Botrytis cinerea isolates from vegetable crops to anilinopyrimidine, phenylpyrrole, hydroxyanilide, benzimidazole, and dicarboximide fungicides. Plant Dis. 91:407413.

Nicot, P., Mermier, M., Vaissiere, B., and Lagier, J. 1996. Differential spore production by Botrytis cinerea on agar medium and plant tissue under near-ultraviolet lightabsorbing polyethylene film. Plant Dis. 80:555-558.

Northover, J. and Matteoni, J. A. 1986. Resistance of Botrytis cinerea to benomyl and iprodione in vineyards and greenhouses after exposure to the fungicides alone or mixed with captan. Plant Dis. 70:398-402.

O'Gorman, D. T., Sholberg, P. L., Stokes, S. C., and Ginns, J. 2008. DNA sequence analysis of herbarium specimens facilitates the revival of Botrytis mali , a postharvest pathogen of apple. Mycologia 100:227-235.

Oliveira, M. S., Amiri, A., Zuniga, A. I., and Peres, N. A. 2017. Sources of primary inoculum of Botrytis cinerea and their impact on fungicide resistance development in commercial strawberry fields. Plant Dis. 101:1761-1768.

Olson-Manning, C. F., Wagner, M. R., and Mitchell-Olds, T. 2013. Adaptive evolution: evaluating emperical support for theoretical predictions. Nat. Rev. Genet. 13:867-877.

Palmer, C. L., Horst, R. K., and Langhans, R. W. 1997. Use of bicarbonates to inhibit in vitro colony growth of Botrytis cinerea. Plant Dis. 81:1432-1438.

Pavan, W., Fraisse, C. W., and Peres, N. A. 2011. Development of a web-based disease forecasting system for strawberries. Comput. Electron. Agric. 75:169175.

Pokorny, A., Smilanick, J., Xiao, C.-L., Farrar, J. J., and Shrestha, A. 2016. Determination of fungicide resistance in Botrytis cinerea from strawberry in the Central Coast region of California. Plant Health Prog. 17:30-34.

Prusky, D. 1996. Pathogen quiescence in postharvest diseases. Annu. Rev. Phytopathol. 34:413-34.

Raposo, R., Delcan, J., Gomez, V., Melgarejo, P., and Corun, C. 1996. Distribution and fitness of isolates of Botrytis cinerea with multiple fungicide resistance in Spanish greenhouses. Plant Pathol. 45:497-505.

Raposo, R., Gomez, V., Urrutia, T., and Melgarejo, P. 2000. Fitness of Botrytis cinerea associated with dicarboxamide resistance. Phytopathology 91:1246-1249.

Ren, W., Shao, W., Han, X., Zhou, M., and Chen, C. 2016. Molecular and biochemical characterization of laboratory and field mutants of Botrytis cinerea resistant to fludioxonil. Plant Dis. 100:1414-1423. 
Saito, S., Cadle-Davidson, L., and Wilcox, W. F. 2014. Selection, fitness, and control of grape isolates of Botrytis cinerea variably sensitive to fenhexamid. Plant Dis. 98:233-240.

Saito, S., Michailides, T. J., and Xiao, C. L. 2016. Fungicide resistance profiling in Botrytis cinerea populations from blueberry in California and Washington and their impact on control of gray mold. Plant Dis. 100:2087-2093.

Seijo, T. E., Chandler, C. K., Mertely, J. C., Moyer, C., and Peres, N. A. 2008. Resistance of strawberry cultivars and advanced selections to anthracnose and Botrytis fruit rots. Proc. Florida State Hortic. Soc. 121:246-248.

Shaw, M. W., Emmanuel, C. J., Emilda, D., Terhem, R. B., Shafia, A., Tsamaidi, D., Emblow, M., and van Kan, J. A. L. 2016. Analysis of cryptic, systemic Botrytis infections in symptomless hosts. Front. Plant Sci. 7:1-14.

Smith, R. B. 1992. Controlled atmosphere storage of Redcoat strawberry fruit. J. Am. Soc. Hortic. Sci. 117:260-264.

Sosa-Alvarez, M., Madden, L. V., and Ellis, M. A. 1995. Effects of temperature and wetness duration on sporulation of Botrytis cinerea on strawberry leaf surfaces. Plant Dis. 79:609-615.

Strand, L. L. 2008. Integrated Pest Management for Strawberries, Second Edition. Regents of the University of California Agriculture and Natural Resources, Oakland, CA.

Strømeng, G. M., Hjeljord, L. G., and Stensvand, A. 2009. Relative contribution of various sources of Botrytis cinerea inoculum in strawberry fields in Norway. Plant Dis. 93:1305-1310.

USDA-NASS. 2016. County Ag Commissioner's Data Listing. Online Publication. United States Department of Agriculture - National Agricultural Statistics Service. https://www.nass.usda.gov/Statistics_by_State/California/Publications/AgComm/ Detail/

USDA-NASS. 2017. Quick Stats. Online publication. United States Department of Agriculture - National Agricultural Statistics Service. https://quickstats.nass.usda.gov/results/E5925A88-F279-356B-89F42AE7B784483F

Van den Bosch, F., Paveley, N., van den Berg, F., Hobbelen, P., and Oliver, R. 2014. Mixtures as a fungicide resistance management tactic. Phytopathology 104:1264-1273.

Veloukas, T., Kalogeropoulou, P., Markoglou, A. N., and Karaoglanidis, G. S. 2014. Fitness and competitive ability of Botrytis cinerea field isolates with dual resistance to SDHI and Qol fungicides, associated with several sdhB and the cytb G143A mutations. Phytopathology 104:347-356.

Weber, R. W. S. 2011. Resistance of Botrytis cinerea to multiple fungicides in northern German small-fruit production. Plant Dis. 95:1263-1269. 
White, G. A., and Georgopoulos, S. G. 1991. Target sites of carboximides. Pages 1-29 in: Target sites of fungicide action, ed. Wolfram Koeller. CRC Press, Boca Raton, FL.

Williamson, B., Tudzynski, B., Tudzynski, P., and Van Kan, J. A. L. 2007. Botrytis cinerea: The cause of grey mould disease. Mol. Plant Pathol. 8:561-580.

Wilson, C. L., Solar, J. M., El Ghaouth, A., and Wisniewski, M. E. 2015. Rapid evaluation of plant extracts and essential oils for antifungal activity against Botrytis cinerea. Plant Dis. 81:204-210.

Xiao, C. L., Chandler, C. K., Price, J. F., Duval, J. R., Mertely, J. C., and Legard, D. E. 2001. Comparison of epidemics of Botrytis fruit rot and powdery mildew of strawberry in large plastic tunnel and field production systems. Plant Dis. 85:901-909.

Yermiyahu, U., Shamai, I., Peleg, R., Dudai, N., and Shtienberg, D. 2006. Reduction of Botrytis cinerea sporulation in sweet basil by altering the concentrations of nitrogen and calcium in the irrigation solution. Plant Pathol. 55:544-552.

Yin, Y. N., Kim, Y. K., and Xiao, C. L. 2011. Molecular characterization of boscalid resistance in field isolates of Botrytis cinerea from apple. Phytopathology 101:986-995.

Young, G. 2015. Anti-tubulin agents. Pages 93-104 in: Fungicide resistance in plant pathogens. H. Ishii and D. W. Hollomon, eds. Springer, Dordrecht, The Netherlands.

Yourman, L. F., Jeffers, S. N., and Dean, R. A. 2001. Phenotype instability in Botrytis cinerea in the absence of benzimidazole and dicarboximide fungicides. Phytopathology 91:307-15.

Ziogas, B. N., Markoglou, A. N., and Spyropoulou, V. 2005. Effect of phenylpyrroleresistance mutations on ecological fitness of Botrytis cinerea and their genetical basis in Ustilago maydis. Eur. J. Plant Pathol. 113:83-100. 